Juan C. Ruiz-Cornejo, David Sebastián* and Maria J. Lázaro

\title{
Synthesis and applications of carbon nanofibers: a review
}

https://doi.org/10.1515/revce-2018-0021

Received April 20, 2018; accepted September 25, 2018; previously published online December 22, 2018

\begin{abstract}
Carbon nanofibers (CNFs) have shown great potential in multiple applications. Their versatility is derived from the possibility of tuning their physical and chemical properties. CNFs can be synthesized using two main methods: the catalytic decomposition of carbon precursors or the electrospinning and carbonization of polymers. The most appropriate method relies on the desired characteristics of the CNFs. Some of their applications include the synthesis of catalysts and catalytic supports, as electrodes for fuel cell devices, in hydrogen storage systems, and in functional nanocomposites. In this review, recent advances in the synthesis and potential applications of CNFs are examined.
\end{abstract}

Keywords: carbon nanofibers; catalytic decomposition; electrospinning.

\section{Introduction}

Carbon nanofibers (CNFs) are filaments of nanometer size (from 3 to $100 \mathrm{~nm}$ in diameter) constituted by stacked graphene layers with a certain orientation with respect to the fiber axis. This sort of material is usually classified into three categories, in accordance with the angle between the graphene layers and the growth axis as shown in Figure 1: parallel (angle $=0^{\circ}$ ), fishbone $\left(0^{\circ}<\right.$ angle $\left.<90^{\circ}\right)$, and platelet $\left(\right.$ angle $\left.=90^{\circ}\right) \quad($ Baker 1989). The structure can be determined by transmission electron microscopy (TEM). It is worth mentioning that although the fishbone designation is still in use, that nomenclature can be misleading. TEM images of tubes, spheres, and cones only show the transversal part, not the perpendicular (thin) portions. The fishbone profile

*Corresponding author: David Sebastián, Instituto de Carboquímica, CSIC, C/Miguel Luesma Castán 4, Zaragoza 50018, Spain, e-mail: dsebastian@icb.csic.es. https://orcid.org/0000-0002-7722-2993

Juan C. Ruiz-Cornejo and Maria J. Lázaro: Instituto de Carboquímica, CSIC, C/Miguel Luesma Castán 4, Zaragoza 50018, Spain is actually a TEM perspective of a spiral conic structure (Vera-Agullo et al. 2007).

Carbon presents a turbostratic nature in CNFs with an average spacing between graphene layers of approximately $0.34 \mathrm{~nm}$, close to that of graphite $(0.335 \mathrm{~nm})$, which is why CNFs are sometimes referred to as graphite nanofibers in the literature. The physical and chemical properties can be distinguished by considering the primary structure of the individual nanofibers, the secondary structure of the agglomeration of filaments, and the tertiary structure derived from the powdered material (Sebastián et al. 2012).

It is important to point out the difference between a carbon nanotube (CNT) and a hollow-core CNF. Both nanostructures present diameters on the nanometer scale and may not be easily distinguishable by electron microscopy techniques. The theoretical definition considers that a nanotube is formed by a single graphene sheet wrapped into a cylindrical tube (single-walled CNT) or several sheets concentrically nested (multiwalled CNT), whereas a CNF is a more general concept, in which the graphene layers might not be continuous. In this sense, CNTs could be considered as a particular case of CNFs, but the discussion is open. Moreover, CNFs may present a tubular aspect (hollow core) or not. In terms of properties, CNTs usually exhibit better mechanical resistance, thermal and electrical conductivities, and other improved structural features; however, compared with the features of CNFs, the main drawbacks are their complicated scalability to produce large-scale batches and their high cost.

Mordkovich (2003) classified carbon fibers according to their purpose by regarding the mechanical property requirements, including Young's modulus $(E)$ and tensile strength $(\sigma)$, as summarized in Table 1. CNFs are simultaneously classified as ultrahigh-strength (up to $12,000 \mathrm{MPa}$ ) and ultrahigh-modulus. The strength of nanofibers can reach $12 \mathrm{GPa}$ (and even $30 \mathrm{GPa}$ ); therefore, nanofibers could be classified as super-high-strength. The mechanical properties of CNFs can differ even when they have an identical origin and equal thickness; it is the fiber structure that determines the difference.

Their high electrical conductivity is of great importance for multiple applications from electronics to composites. Generally, carbon materials are an electrical conductor due 


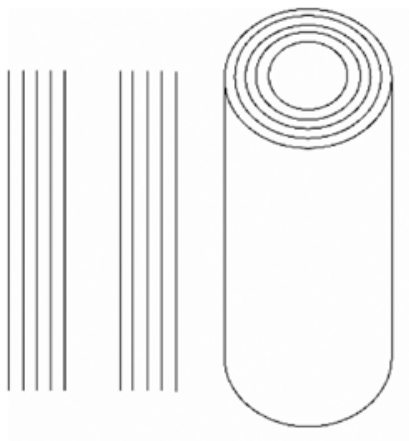

Parallel

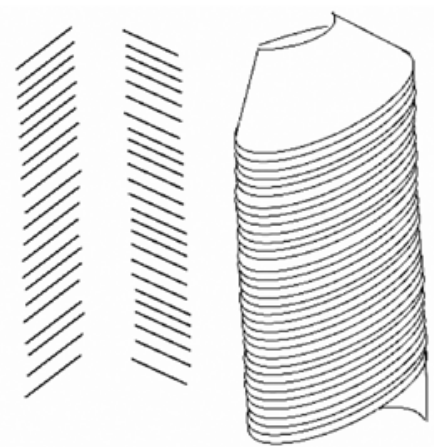

Fishbone
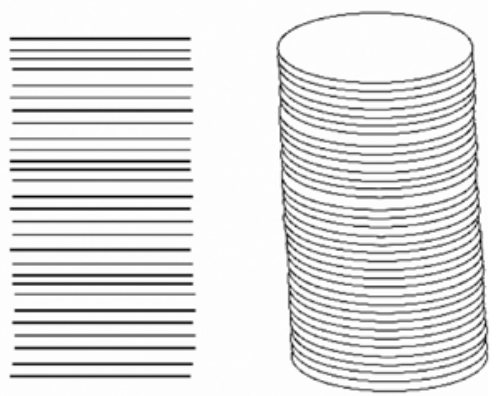

Platelet

Figure 1: Representations of different types of carbon nanofibers.

Table 1: Classification of carbon fibers according to their mechanical properties ( $E$ : Young's modulus and $\sigma$ : tensile strength).

\begin{tabular}{lrr}
\hline & $\boldsymbol{E}(\mathrm{GPa})$ & $\boldsymbol{\sigma}(\mathrm{MPa})$ \\
\hline General purpose & $50-100$ & $500-1000$ \\
High modulus & $300-400$ & $2000-2500$ \\
Ultrahigh modulus & $450-700$ & $2000-2500$ \\
High strength & $200-250$ & $2500-4500$ \\
Ultrahigh strength & $200-250$ & $5000-6000$ \\
High performance & $300-350$ & $3000-5500$ \\
Carbon nanofibers & $270-600$ & $4500-12,000$ \\
\hline
\end{tabular}

to the presence of delocalized electrons ( $\pi$ orbitals) that can freely move throughout the structure. In ordered graphite, the conductivity is anisotropic, with values on the order of $2.5 \times 10^{6} \mathrm{~S} / \mathrm{m}$ and $1 \times 10^{4} \mathrm{~S} / \mathrm{m}$ parallel and perpendicular to graphene layers, respectively (Kinoshita 1988). However, a porous carbon material presents a considerably lower conductivity due to the presence of several and important resistive contributions: contact between carbon crystalline domains, contact between particles, and contact between grains or aggregates of particles (Pandolfo and Hollenkamp 2006). All these resistive barriers result in a lower apparent electrical conductivity, also occurring in CNFs (Sebastián et al. 2013a).

The mechanical and electrical properties of CNFs rely on, among other features, the degree of graphitization. One common strategy to modify the degree of graphitization is through heat treatment (Ozkan et al. 2010, Ramos et al. 2013). A well-developed graphene alignment characterizes highly graphitic CNFs, and high-temperature heat treatments can significantly induce the alignment of the graphene structure and increase the degree of graphitization of CNFs (Zhu et al. 2003). The graphitization extent can also be altered by the presence of other elements including $\mathrm{Ni}$, $\mathrm{Ti}$, or $\mathrm{Si}$, where the formation of intermediate species interferes with the graphitization process, favoring certain mechanisms to improve the structural characteristics of CNFs (Garcia et al. 2009, 2010, Cameán et al. 2012).

In addition, CNFs can be chemically treated to increase the number of surface oxygen groups or to develop a higher specific surface area. Functionalizing in acidic oxidizing media (for example, nitric and nitric/sulfuric mixtures) introduces a variation in the surface chemistry and promotes hydrophilicity in CNFs, which might be beneficial to promote good dispersion in aqueous solutions of the carbon particles. Despite enhancing the hydrophilicity of CNFs, the introduction of surface oxygen groups by oxidation may also cause a decrease in the electrical conductivity (Sebastián et al. 2010).

Due to the exceptional properties introduced above, the use of CNFs presents several potential applications: catalysts and catalytic support, hydrogen storage systems, functional composites, sensors, and others. Some previous reviews have examined the process of methane catalytic decomposition, in which nanofilaments are obtained (Ashok et al. 2010), and the thermodynamic equilibrium in the carbon deposition from C-H-O mixtures (Jaworski et al. 2017).

Carbon nanofibers are promising materials that can be synthesized with different morphologies, diameters, and lengths. Their good mechanical and electrical properties can also be adjusted or modified using different treatments, such as thermal treatments or doping with other elements. CNFs are broadly studied in the published literature, and excellent reviews have been previously reported covering the most important findings two decades ago (Rodriguez 1993, De Jong and Geus 2000). Therefore, the purpose of this work is to update the state of the art and collect some recent literature related to the different paths of synthesizing CNFs as well as their potentiality for different applications. 


\section{Synthesis of CNFs}

\subsection{CNF growth by catalytic decomposition of carbon precursors}

Carbon nanofibers can be synthesized through the catalytic decomposition of carbon-containing gases in the presence of metal particles (catalysts). Carbon sources are not very restrictive, and many hydrocarbons, mainly $\mathrm{C}_{1}-\mathrm{C}_{6}$, have indeed been studied for this process. The raw materials for $\mathrm{CNF}$ production by chemical vapor deposition (CVD) technology are not expensive, with the most common gases being methane, ethylene, acetylene, and propylene (Danilov et al. 2008). On the other hand, the most important metals that catalyze the growth of CNFs are iron, cobalt, and nickel; however, chromium, vanadium, and molybdenum have also been studied (Rodriguez 1993, Ashok et al. 2010). A particular advantage of CNFs is that its mass production is substantially more cost-effective than the productions of other similar carbon nanostructures such as singlewalled CNTs.

\subsubsection{Mechanism}

The growth mechanism starts with the hydrocarbon decomposition on the catalytic metal particle. This leads to a continuous carbon uptake by particles and output of well-organized filaments of hexagonal $\mathrm{sp}^{2}$-carbon. This process is illustrated in Figure 2.

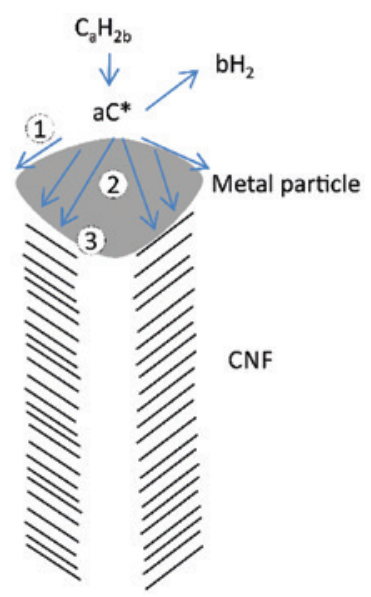

Figure 2: Schematic of the CVD growth mechanism of a CNF. (1) Adsorption of the hydrocarbon $\left(\mathrm{C}_{a} \mathrm{H}_{2 b}\right)$; (2) diffusion of carbon atoms through the metal particle; and (3) precipitation of graphene layers.
Alternative modes of nucleation have been observed when the catalytic particle is on a substrate (Lobo 2017):

(a) On a flat basal contact. Selective nucleation occurs at the flat contact interface between the catalyst nanoparticle and substrate.

(b) On an external crystalline face. Nucleation takes place on the crystal face that is not in contact with the substrate. The growth is similar to the previous case, but the particle is in contact with the substrate.

(c) Inside an embedded conical contact. When the metal nanoparticle is embedded in a carbon substrate, the nucleation of a CNF starts at particular atomic arrangement characterized by a conical contact between the catalyst and substrate.

Particular CNFs are relatively short and are difficult to align, assemble, and process for certain applications, experience low product yield, require expensive manufacturing equipment, and exhibit significant amounts of catalyst residue (Zhang et al. 2014).

The difference between a CNF and a CNT both synthesized by CVD is given by their difference in morphology. A CNF has a stacked cone morphology with a finite cone angle, whereas a CNT has a theoretical cone angle of zero degrees (Ngo et al. 2007).

\subsubsection{Control parameters}

The control of the growth process, aimed at obtaining a desirable shape, size, and structure, can be done through an understanding of the kinetics of the nucleation and growth of CNTs (Lobo 2017). A constant bulk diffusion flux takes place in each catalyst nanoparticle, where two distinct catalytic areas can be described: (1) surface catalysis producing carbon atoms in certain facets of the metal particle and (2) graphene nucleation and growth in other different areas. Kinetic studies based on thermogravimetric analyses have evidenced different mechanisms of carbon diffusion from the reaction sites to the deposition area. The deposition of carbon does not alter the structural properties of Ni particles, suggesting that carbon diffusion takes place on the surface (Pinilla et al. 2008). Additionally, a mechanism of catalytic carbon formation has been proposed in which the bulk diffusion of carbon atoms through the catalyst is produced. This conclusion is based on thermogravimetric kinetic studies using hydrocarbons as precursors reacting on metals (Lobo 2017).

Figure 3 shows growth models for the different types of carbon synthesized using CVD. The morphology of the CNF depends on the shape of the catalytic particle. 

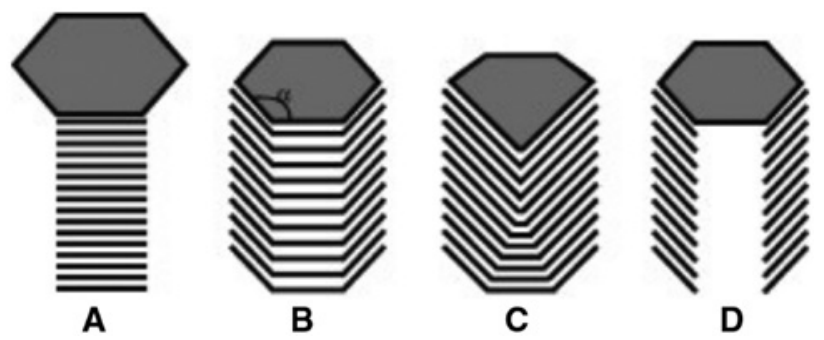

Figure 3: (A) Graphenic layers precipitate from the base surface of the catalyst particle. (B) Graphenic layers precipitate from both the base and slanting surfaces at the same speed, and the $d$ spacing in the base plane is larger than that in slanting planes. (C) The catalyst particle gradually changes to a conical shape. (D) Graphene layers precipitate from inclined surfaces.

Structures proposed by Zheng and coworkers, from Carbon, 42(3), Zheng et al. A model for the structure and growth of carbon nanofibers synthesized by the CVD method using nickel as a catalyst, 635-640, Copyright (2004), with permission from Elsevier (Zheng et al. 2004).

The diameter of the filament depends on the size of the individual catalyst particle (Rodriguez 1993, Chen et al. 2005). The catalyst nanostructure can be tuned by depositing a few monolayers of the catalytically active metal onto a supporting material (e.g. alumina, silica, or carbon), followed by nucleation to obtain small particles (Lamber et al. 1988, He et al. 2011). The reaction of a suitable carbon-containing gas on these catalysts gives rise to carbon nanostructures with the same diameter as that of the starting catalyst particles (Baker et al. 1973).

The pyrolytic temperature can also affect the morphology of CNFs (Yuan and Ryu 2004). Yuan et al. have obtained CNFs with different morphologies by only changing the temperature: straight $\mathrm{CNFs}$ at $500^{\circ} \mathrm{C}$ and twisted CNFs at more than $550^{\circ} \mathrm{C}$.

Table 2 summarizes data concerning the synthesis of CNFs through catalytic decomposition. In general, catalytic alloys, e.g. with $80 \%-40 \%$ nickel, have stronger catalytic activity than pure phases, in this case, nickel (Nishiyama and Tamai 1974). There is direct evidence for carbide-assisted growth as well. It has been observed that $\mathrm{Fe}_{3} \mathrm{C}$ can induce the growth of CNFs at temperatures in the interval of $600^{\circ} \mathrm{C}-700^{\circ} \mathrm{C}$ (Yu et al. 2016a). However, the growth rate of CNFs grown from Fe is substantially higher than that of CNFs grown from $\mathrm{Fe}_{3} \mathrm{C}$ (He et al. 2011). Moreover, the structure of CNFs grown from $\mathrm{Fe}_{3} \mathrm{C}$ is a bambootype with a rounded growth front and is different from the structure of those grown from Fe, characterized by a faceted growth front.

The CNF surface area varies with catalyst characteristics, as has been reported by Rodriguez (1993). The surface area of CNFs obtained from the decomposition of ethylene-hydrogen over $\mathrm{Cu}$-Ni powder ranges from $10 \mathrm{~m}^{2} / \mathrm{g}$ for CNFs obtained using copper-rich powders to $250 \mathrm{~m}^{2} / \mathrm{g}$ for the powdered catalyst with a large fraction of nickel, whereas it decreases to approximately $75 \mathrm{~m}^{2} / \mathrm{g}$ for CNFs formed from pure nickel (Figueiredo et al. 1990). The activation of the nanofibers in melted potassium hydroxide is an alternative strategy to increase the surface area (Danilov et al. 2008).

The catalytic disproportionation of $\mathrm{CO}$ using Ni supported on alumina-silica with $\mathrm{H}_{2}$ can produce open-edge graphitic structures similar to stacked cone arrays (Jiao et al. 1996). Different carbon nanostructures synthesized from $\mathrm{CO}$ are obtained by introducing $\mathrm{H}_{2}$ (Yu 2005). Hydrogen can have several simultaneous effects during the decomposition process. On one hand, the presence of hydrogen is believed to influence the surface orientations of the catalysts by lattice restructuring, which consequently influences the deposited carbonaceous structure (Anderson and Rodriguez 1999). On the other hand, for both the platelet and fishbone structures, the carbon edges are exposed rather than basal carbon atoms, which are characterized by a higher energy content. This is made possible by the presence of $\mathrm{H}_{2}$ because it satisfies the valence of open-edge planes, and without $\mathrm{H}_{2}$, edges do not form (Nolan et al. 1998). When no hydrogen is present on the surface, particulate carbon is deposited as closed shells or as parallel tubes. Thus, hydrogen plays an essential role in the process by surface reconstruction, keeping the catalyst surface clean of carbon, and satisfying hanging bonds (Yu 2005).

Variations in the choice of the metal and the growth temperature can alter the ordering of the graphite planes from parallel to fishbone. Parallel CNFs can be grown, especially using $\mathrm{CO}$, from iron and cobalt particles as well as from nickel at elevated temperatures. Moreover, the CNF production yield depends on the combination of the type of nickel catalyst and the carbon-containing species (Toebes et al. 2002).

The orientation of graphene nanocones to more acute angles with respect to the fiber axis, as well as the formation of hollow-core nanofibers, with increased temperature $\left(700^{\circ} \mathrm{C}-750^{\circ} \mathrm{C}\right)$ has been observed using TEM, in contrast with the full-core nanofibers obtained at $550^{\circ} \mathrm{C}-650^{\circ} \mathrm{C}$. The apparent density, and consequently, the compaction degree, is mainly influenced by the pore volume. The thinner the nanofibers, the higher the pore volume and the lighter the resulting material. The apparent electrical conductivity increases with the synthesis temperature. For a similar compaction degree (in terms of 
Table 2: Summary of synthesis conditions for the growth of CNFs by decomposition.

\begin{tabular}{|c|c|c|c|c|c|}
\hline Catalyst & Carbon precursor & $\begin{array}{r}\text { Temperature } \\
\left({ }^{\circ} \mathrm{C}\right)\end{array}$ & Type of CNF & Diameter $(\mathrm{nm})^{\mathrm{a}}$ & Reference \\
\hline $\mathrm{Ni}$ & $\mathrm{CO}, \mathrm{CO}_{2}, \mathrm{H}_{2}$ & $400-600$ & Fishbone (open edge) & $16-24$ & (Jiao et al. 1996) \\
\hline $\mathrm{Ni}$ & $\mathrm{C}_{2} \mathrm{H}_{2}$ & $<700$ & Fishbone $\left(20^{\circ}\right)$ & - & (Hammel et al. 2004) \\
\hline $\mathrm{Ni}$ & Natural gas $/ \mathrm{H}_{2} / \mathrm{S}$ & 1127 & Stacked-cup & $40-100$ & (Martin-Gullon et al. 2006) \\
\hline $\mathrm{Ni}$ & $n$-Hexane & 500 & - & 30 & (Li et al. 2016b) \\
\hline $\begin{array}{l}\mathrm{Ni} \text {-containing } \\
\text { polymeric beads }\end{array}$ & $\mathrm{C}_{2} \mathrm{H}_{2}$ & 600 & Tubular & 100 & (Talreja et al. 2016) \\
\hline Ni foam & $\mathrm{C}_{2} \mathrm{H}_{4} / \mathrm{H}_{2} / \mathrm{N}_{2}$ & 600 & - & 100 & (Hyun et al. 2016) \\
\hline Ni foam & $\mathrm{C}_{2} \mathrm{H}_{2}$ & $400-750$ & - & $78-375$ & (Sridhar et al. 2018) \\
\hline $\begin{array}{l}\text { Ni nanowire } \\
\text { template }\end{array}$ & $\mathrm{C}_{2} \mathrm{H}_{2} / \mathrm{H}_{2}$ & 500 & Helical fibers & 5 & (Li et al. 2016a) \\
\hline $\mathrm{Ni} / \mathrm{SiO}_{2}$ & $\mathrm{C}_{2} \mathrm{H}_{4}$ & $450-750$ & - & - & (Díaz et al. 2013) \\
\hline $\mathrm{Ni}-\mathrm{Cr}$ & Chlorobenzene $/ \mathrm{H}_{2}$ & 600 & - & $20-40$ & (Kenzhin et al. 2018) \\
\hline $\mathrm{Ni}-\mathrm{Cu}$ & $\mathrm{C}_{2} \mathrm{H}_{4} / \mathrm{H}_{2}$ & 600 & - & - & (Rodriguez 1993) \\
\hline $\mathrm{Ni}-\mathrm{Cu}-\mathrm{Al}_{2} \mathrm{O}_{3}$ & $\mathrm{CH}_{4}$ & $500-900$ & Fishbone & $20-60$ & (Pinilla et al. 2008) \\
\hline $\mathrm{Ni}-\mathrm{Cu}-\mathrm{Al}_{2} \mathrm{O}_{3}$ & $\mathrm{C}_{2} \mathrm{H}_{6}$ & $550-750$ & Fishbone & $20-30$ & (Pinilla et al. 2011a) \\
\hline $\mathrm{Ni}-\mathrm{Cu}-\mathrm{Al}_{2} \mathrm{O}_{3}$ & $\mathrm{CH}_{4}$ & 700 & Fishbone & 55 & (Alegre et al. 2015) \\
\hline $\mathrm{Ni} / \mathrm{SiO}_{2}-\mathrm{Al}_{2} \mathrm{O}_{3}$ & $\mathrm{CO} / \mathrm{CO}_{2} / \mathrm{N}_{2} / \mathrm{H}_{2}$ (up to $3 \%$ ) & $472-512$ & Fishbone $\left(5^{\circ}-35^{\circ}\right)$ & - & (Nolan et al. 1998) \\
\hline $\mathrm{Ni}_{3} \mathrm{C}$ & $n$-Hexane & 350 & Twisted & 45 & (Li et al. 2016b) \\
\hline $\mathrm{Ni} / \mathrm{SiO}_{2}$ & $20 \% \mathrm{CO} / 7 \% \mathrm{H}_{2}(\mathrm{Ar})$ & 550 & Fishbone & 50 & (Toebes et al. 2002) \\
\hline $\mathrm{Ni} / \mathrm{Mg}-\mathrm{Al}_{2} \mathrm{O}_{3}$ & $\mathrm{CH}_{4} / \mathrm{H}_{2}(1: 1)$ & $500-540$ & Parallel or fishbone & 10 & (Helveg et al. 2004) \\
\hline \multirow[t]{3}{*}{$\mathrm{Ni} / \mathrm{Al}_{2} \mathrm{O}_{3}$} & $\mathrm{C}_{2} \mathrm{H}_{2} / \mathrm{H}_{2} / \mathrm{N}_{2}$ & 550 & $\begin{array}{l}\text { Fishbone } \\
\text { (coil-like shape) }\end{array}$ & $35-70$ & (Zheng et al. 2004) \\
\hline & & 600 & $\begin{array}{l}\text { Fishbone (few } \\
\text { coil-like shapes) }\end{array}$ & 50 & \\
\hline & & 700 & Platelet and fishbone & $10-300$ & \\
\hline \multirow[t]{2}{*}{$\mathrm{Ni}-\mathrm{Fe}$} & $\mathrm{CO} / \mathrm{H}_{2}$ & 580 & Platelet & $100-200$ & (Tanaka et al. 2004a,b) \\
\hline & & 630 & Tubular & $20-40$ & \\
\hline $\mathrm{Ni}-\mathrm{MgO}$ & $\mathrm{CH}_{4}$ & 650 & Fishbone & $20-40$ & (Hwang et al. 2002) \\
\hline \multirow{3}{*}{$\begin{array}{l}\text { Co/amorphous } \\
\text { carbon }\end{array}$} & $\mathrm{C}_{2} \mathrm{H}_{4} / \mathrm{H}_{2}(4: 1)$ & 500 & - & $0-16$ & (Rodriguez 1993) \\
\hline & & 600 & & $5-30$ & \\
\hline & & 700 & & $10-40$ & \\
\hline \multirow[t]{3}{*}{ Co/graphite } & $\mathrm{C}_{2} \mathrm{H}_{4} / \mathrm{H}_{2}(4: 1)$ & 500 & - & $0-20$ & (Rodriguez 1993) \\
\hline & & 600 & & $0-27$ & \\
\hline & & 700 & & $15-55$ & \\
\hline \multirow{2}{*}{$\begin{array}{l}\text { Co-Mo }(9: 1) / \\
\text { carbon black }\end{array}$} & $\mathrm{C}_{2} \mathrm{H}_{4} / \mathrm{H}_{2}(4: 1)$ & 480 & Hollow/fishbone/10 & - & (Lim et al. 2004) \\
\hline & & 600 & $\begin{array}{l}\text { Non-hollow/fishbone } \\
40,100\end{array}$ & & \\
\hline \multirow{2}{*}{$\begin{array}{l}\text { Co-Mo(9:1)/ } \\
\text { titania }\end{array}$} & $\mathrm{C}_{2} \mathrm{H}_{4} / \mathrm{H}_{2}(4: 1)$ & 480 & Hollow/fishbone/15 & $10-40$ & (Lim et al. 2004) \\
\hline & & 600 & Hollow/parallel/20 & & \\
\hline \multirow{2}{*}{$\begin{array}{l}\text { Co-Mo(9:1)/ } \\
\text { carbon black }\end{array}$} & $\mathrm{CO} / \mathrm{H}_{2}(4: 1)$ & 480 & Hollow/fishbone/15 & - & (Lim et al. 2004) \\
\hline & & 600 & Hollow/parallel/20 & & \\
\hline \multirow[t]{2}{*}{$\begin{array}{l}\text { Co-Mo(9:1)/ } \\
\text { titania }\end{array}$} & $\mathrm{CO} / \mathrm{H}_{2}(4: 1)$ & 480 & $\begin{array}{l}\text { Hollow or non-hollow/ } \\
\text { fishbone } / 10\end{array}$ & - & (Lim et al. 2004) \\
\hline & & 600 & Hollow/parallel/20 & & \\
\hline \multirow[t]{2}{*}{$\mathrm{Fe}$} & $\mathrm{CO} / \mathrm{H}_{2}$ & 580 & Platelet & $100-200$ & (Tanaka et al. 2004b) \\
\hline & & 630 & Tubular & $20-40$ & \\
\hline \multirow[t]{2}{*}{$\mathrm{Fe}$} & Isopropyl alcohol, & 650 & - & 65-135 (avg 100.7) & (He et al. 2011) \\
\hline & water vapor, $\mathrm{H}_{2}$ & 725 & & $30-80(\operatorname{avg} 55.3)$ & \\
\hline $\begin{array}{l}\text { Ferroin } \\
\text { perchlorate }\end{array}$ & $\mathrm{C}_{2} \mathrm{H}_{4} / \mathrm{Ar} / \mathrm{O}_{2} / \mathrm{H}_{2}$ & 500 & Amorphous fibers & 29 & (Avraham et al. 2017) \\
\hline $\mathrm{Fe}_{3} \mathrm{O}_{4}$ & $\mathrm{CO} / \mathrm{H}_{2}$ & 600 & Platelet & $35-360$ (avg 116) & (Yu 2005) \\
\hline $\mathrm{Fe}-\mathrm{Mo} / \mathrm{MgO}$ & $\mathrm{CH}_{4}$ & $600-800$ & Parallel/bamboo & $20-50$ & (Pinilla et al. 2011b) \\
\hline $\mathrm{Fe} / \mathrm{Al}_{2} \mathrm{O}_{3}$ & $\mathrm{CH}_{4}$ & $700-900$ & Parallel/bamboo & $\sim 20$ & (Torres et al. 2012) \\
\hline $\mathrm{Fe}-\mathrm{Mo} / \mathrm{Al}_{2} \mathrm{O}_{3}$ & $\mathrm{CH}_{4}$ & $700-900$ & Parallel/bamboo & $10-60$ & (Torres et al. 2014) \\
\hline
\end{tabular}


Table 2 (continued)

\begin{tabular}{llllll}
\hline Catalyst & Carbon precursor & $\begin{array}{r}\text { Temperature } \\
\left({ }^{\circ} \mathrm{C}\right)\end{array}$ & Type of CNF & Diameter (nm) & Reference \\
\hline $\mathrm{Fe} / \mathrm{Al}_{2} \mathrm{O}_{3}$ & $\mathrm{CO} / \mathrm{H}_{2}$ & 600 & Fishbone-tubular & $10-60$ (avg 45) & $($ Yu 2005) \\
$\mathrm{Fe} / \mathrm{C} / \mathrm{SiO}_{2}$ & $\mathrm{C}_{2} \mathrm{H}_{2}$ & 620 & Fishbone & $50-400$ & (Danilov et al. 2008) \\
$\mathrm{Fe}{ }_{3} \mathrm{C}$ & Isopropyl alcohol, water & 600 & Bamboo-like & $28-45$ & (He et al. 2011) \\
& vapor, $\mathrm{H}_{2}$ & 650 & & $38-78($ avg 59.5) & \\
& & 725 & & $38-65($ avg 53.0) \\
\hline
\end{tabular}

aavg, average.

solid volume fraction), the precise value of conductivity is a function of not only the structural and morphological features but also the porosity. Further analysis has been carried out applying percolation theory to the experimental data, and the results suggest that the electrical conductivity of CNFs is the result of a complex combination of variables in which the orientation of the graphene layers and the morphology play a determining role (Sebastián et al. 2013a).

The crystal size of the catalyst also affects the growth of CNFs. Li et al. (2006) have found that small Ni crystals yield a low growth rate and fast deactivation and thus a low final yield of CNFs. Large Ni crystals reduce the growth rate because of the low surface area. An optimum growth rate and yield of CNFs can be achieved on optimally sized $\mathrm{Ni}$ crystals of approximately $34 \mathrm{~nm}$. Pinilla et al. (2009) have found that the combination of doping of $\mathrm{Ni}$ with $\mathrm{Cu}$ together with low crystallite sizes in the catalyst results in a large carbon accumulation capacity.

Tanaka et al. (2004b) have found an effect of the catalyst on the degree of the graphitization of CNFs grown from $\mathrm{CO} / \mathrm{H}_{2}$ over $\mathrm{Fe}$ and $\mathrm{Fe}-\mathrm{Ni}$ (6:4) alloy catalysts. The highest graphitization is observed in a temperature range from $560^{\circ} \mathrm{C}$ to $675^{\circ} \mathrm{C}$. The catalyst particle observed on the top of the CNFs with the highest graphitization looks similar to a hexagonal column that governs the shape of the fiber. The size of the catalyst is slightly larger than the diameter of the fiber.

Carbon nanofibers can be synthesized under different $\mathrm{CH}_{4} / \mathrm{H}_{2}$ compositions (Sebastián et al. 2009). The presence of a low partial pressure of hydrogen in the reaction gas improves the carbon structural ordering by an increase in crystal size of approximately $10 \%$ with respect to the CNFs produced with pure methane. On the other hand, the presence of hydrogen provokes a decrease in surface area and pore volume, which are also important features when considering CNFs as a catalyst support.

Some authors have reported CNFs of several centimeters in length (Zhang et al. 2013, Bai et al. 2018). These nanofibers are characterized by excellent mechanical properties, a tensile strength of more than $80 \mathrm{GPa}$ being within the parameters of the CNF definition.

\subsection{CNFs synthesized by electrospinning and carbonizing polymers}

The electrospinning technique consists of the application of a strong electrostatic field to a capillary connected to a reservoir containing a polymer solution (Bognitzki et al. 2001). It is an effective technique to produce polymeric nanofibers, allowing the tailoring of the fiber morphology, chemical composition, fibrous architecture, and functionality. Electrospinning has been used to prepare nanofibers from a few tens of nanometers to a few micrometers in different forms, such as nonwoven mats (webs), yarns, and others (Inagaki et al. 2012). It is a relatively simple and low-cost strategy to produce continuous nanofibers from polymer solutions or melts (Inagaki et al. 2012).

The main electrospinning processing parameters are the solution concentration of the polymer, spinning voltage, working distance, and solution feeding rate; all influencing the morphology of the polymeric fibers. The synthesis of CNFs comprises the spinning of polymeric precursor fibers, followed by a thermal treatment. The fiber size decreases with increasing carbonization temperature (Ruiz-Rosas et al. 2010). Commonly used solvents are $\mathrm{CS}_{2}$, acetone, $\mathrm{CHCl}_{3}$, tetrahydrofuran (THF), cyclohexane, water, toluene, and dimethylformamide (DMF) (Megelski et al. 2002).

\subsubsection{Mechanism}

In the process, a viscoelastic solution of polymer is charged by a high DC or AC voltage due to the potential difference between the syringe and a grounded target, as 
shown in Figure 4. The repulsion among charges on the surface of the drop at the tip of the syringe (spinneret) competes with the surface tension, which tends to stabilize the drop. Once a critical condition at which surface charge repulsion dominates is reached, a jet is drawn from the spinneret under a constant flow rate. The accelerating jet decreases in diameter with increasing external applied field; the surface charge repulsion continually draws on the jet until a point is reached where the axis of the jet bends, and the jet begins whipping. As the solvent evaporates, the jet solidifies to form thin fibers, which are deposited on the grounded target (or collector) (Inagaki et al. 2012).

Once the electrospun polymer nanofibers are obtained, they have to be carbonized to obtain CNFs. The carbonization process is usually carried out at approximately $1000^{\circ} \mathrm{C}$. During the carbonization, the polymer nanofibers exhibit a weight loss and shrinkage that reduces the fiber diameter.

\subsubsection{Control parameters}

The spinnability of a polymer solution and the morphology of the resulting fibers depend strongly on three factors: the properties of the polymer solution, processing conditions, and atmospheric conditions (Inagaki et al. 2012).

The properties of the polymer solution are the most dominant factors in controlling the morphology (i.e.

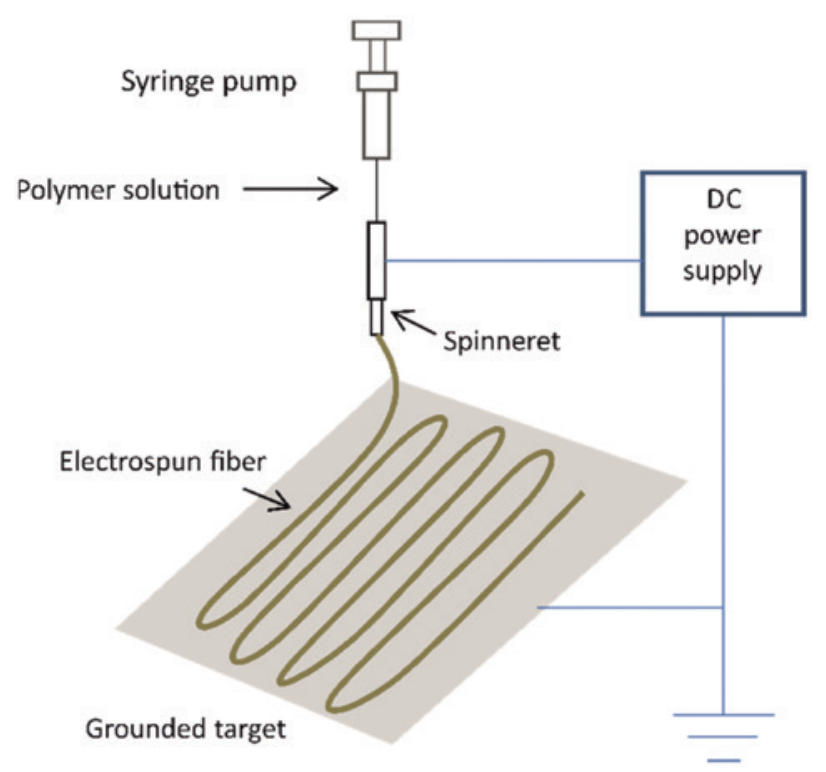

Figure 4: Schematic of the electrospinning technique of a CNF. diameter and uniformity). The main influencing properties of the polymer solution are its surface tension, electrical conductivity, dielectric constant, and viscosity. At the same time, the viscosity depends on the polymer (concentration, molecular weight, and structure), solvent (vapor pressure, diffusivity in air, etc.), and additives (salts, surfactants, etc.). Typically, the diameter of the electrospun fibers decreases greatly with decreasing polymer concentration and with increasing electrical conductivity of the solution.

The processing conditions that affect the process are the hydrostatic pressure in the capillary tube, the electric potential at the capillary tip, and the distance between the tip and the grounded target. The important atmosphere conditions are temperature, humidity, and air velocity in the electrospinning chamber (Doshi and Reneker 1995).

To fabricate CNFs using the electrospinning method, it is necessary to prepare the polymer nanofibers as the precursor to the CNFs. The properties of the final CNFs are decided by the type of polymer solution and the processing parameters. Carbon fibers are normally produced from three polymeric precursors: polyacrylonitrile (PAN), cellulose, or pitch. Among the various precursors for producing CNFs, PAN is the most commonly used polymer, mainly due to its high carbon yield (up to 56\%) and flexibility. PAN is the precursor for approximately $90 \%$ of CNFs manufactured today (Rahaman et al. 2007). In addition, polyvinyl alcohol (PVA), polyimides (PIs), polybenzimidazole, poly(vinylidene fluoride), phenolic resin, and lignin have also been investigated. Theoretically, any fibrous material with a carbon backbone can be used as a precursor to CNFs (Yang et al. 2011). There is no common relation between the control parameters and the different polymers that lead to the synthesis of a homogeneous thin fiber (Inagaki et al. 2012).

The fiber diameters obtained in the electrospinning process depend on the jet size and the polymer contents in the jet. During the traveling of a solution jet from the tip to the grounded target, the main jet can split into multiple jets, giving rise to different diameters. When there is no splitting, one of the main influencing parameters is the solution viscosity. A higher viscosity produces a larger fiber diameter (Doshi and Reneker 1995).

Several strategies have been reported in the literature to tune the porous texture and morphology of electrospun CNFs. Megelski et al. (2002) have reported that a nanoporous morphology combined with small diameters $(10-1000 \mathrm{~nm})$ can give rise to a large surface area $\left(100-1000 \mathrm{~m}^{2} / \mathrm{g}\right)$. It is also possible to obtain porous nanofibers when a volatile solvent is used (Bognitzki et al. 2001). Electrospun poly(methyl methacrylate) 
(PMMA) fibers from $\mathrm{CHCl}_{3}$ and from THF exhibit a nanoporous surface texture (Megelski et al. 2002). CNFs produced from electrospinning PAN have been treated with different physical or chemical activation processes using steam (Guo et al. 2009), $\mathrm{CO}_{2}$ (Ra et al. 2009), or alkali hydroxide (KOH or $\mathrm{NaOH}$ ) (Xu et al. 2010, Ma et al. 2013) to create pores within the nanofibers to obtain a high surface area and microporous structure. The electrospinning method allows for the formation of yarn, web, or mat structures. This kind of conformation is suitable to use as an electrode material for batteries or supercapacitors (Feng et al. 2014).

Kim et al. (2006) have studied the effect of temperature during the carbonization of electrospun PAN with a very long and straight morphology. At $700^{\circ} \mathrm{C}$, the CNFs change from straight to undulated due to a great weight loss together with gas evolution. When webs were thermally treated at $1000^{\circ} \mathrm{C}, 1500^{\circ} \mathrm{C}, 2000^{\circ} \mathrm{C}$, and $2500^{\circ} \mathrm{C}$, there were no large changes in macromorphologies, as is typical for a nongraphitizable carbon material. At $2800^{\circ} \mathrm{C}$, there was a morphological transformation from a round to a faceted cross-section and from a smooth to wrinkled surface, mainly due to the large density change caused by the liberation of heteroatoms and the densification of carbon atoms.

The length of the electrospun fibers can be several kilometers. The length is limited by parameters such as the supply of liquid polymer and the time required for the fiber to be spun (Reneker and Chun 1996). To obtain special nanofiber sizes and features, such as a thin diameter, porous nanofibers, multiple components, a core-shell structure, or a simple posttreatment process, combinations of spinning side-by-side with mixing technologies have developed electrospun blended polymers (Song and Shen 2014). Electrospinning is a simple process for fabricating nonwoven nanofiber mats with a high surface area and porosity (Song and Shen 2014).

Several precursors have been investigated for the electrospinning process, determining the CNF properties. Table 3 summarizes some processing conditions in the electrospinning of polymers to synthesize CNFs including the composition of the polymer precursor, solvent, applied potential, and carbonization temperature.

Polyacrylonitrile has been widely used to fabricate nanofibers due to its facile carbonization process. PANderived nanofibers can also be modified and functionalized after carbonization by an activation process with steam, air or a chemical activation agent. The use of PAN also allows the possibility of preparing nanofiberbased paper (Ra et al. 2009). Another approach to further increase the surface area is using a sacrificial polymer that is removed after the electrospinning process.

Apart from PAN, several other polymers have been used to synthesize CNFs by electrospinning. Some authors have reported interesting results. To obtain porous CNFs, Abeykoon et al. (2015) have used PAN as the carbonizing polymer with PMMA as the sacrificial polymer.

Pitch is an attractive raw material for the carbon fiber precursor due to its low cost and high carbon yield. The electrospinning of pitch depends on the viscosity and on the stretchability that results from the molecular structure, which is tunable via synthetic processing of the raw materials (Yang et al. 2014). Park et al. (2004) have carried out electrospinning from a petroleum-derived isotropic pitch precursor with a broad weight distribution. After separating the DMF fraction from the isotropic pitch precursor, a THF solution of the DMF-insoluble pitch fraction is electrospun into a web, stabilized, and carbonized. PAN-based carbon fibers exhibit the highest tensile strengths, whereas the pitch-based carbon fibers exhibit a high modulus and high thermal conductivity (Ruiz-Rosas et al. 2010).

Lignin has been used as a precursor of carbon submicrofibers (Ruiz-Rosas et al. 2010). The use of blends of lignin and synthetic polymers improves the melt extrusion to produce fibers. These blends turn into CNFs with a proper thermal treatment (Kubo and Kadla 2005). The lignin/synthetic polymer blend composition affects the surface morphology of the CNFs (Kubo and Kadla 2005). Immiscible lignin-PP fibers result in hollow and/or porous CNFs, whereas those obtained from miscible lignin-PET fibers have a smooth surface.

Polyvinyl alcohol has been used as a carbon precursor; however, it easily decomposes at high temperatures, so it gives a low carbon yield (Inagaki et al. 2012). Zhu et al. (2006) have prepared CNFs from PVA by electrospinning $(18 \mathrm{kV})$ and carbonization $\left(600^{\circ} \mathrm{C}\right.$, Ar). PVA and ferrous acetate were dissolved in water to produce $\mathrm{Fe}_{3} \mathrm{O}_{4}$-filled CNFs.

Ju et al. (2017) have prepared PV-based CFs with a honeycomb-like carbon porous structure by electro-blown spinning $(40 \mathrm{kV})$, a pretreatment and a carbonization process. Pores are obtained using polytetrafluoroethylene (PTFE) as a sacrificial polymer. PTFE is pyrolyzed during carbonization. The diameter of the resulting CNFs decreases with increasing concentrations of PTFE in the precursor solution.

Lai et al. (2014) have prepared electrospun CNFs by electrospinning aqueous mixtures of alkali lignin with PVA into composite nanofiber mats, followed by stabilization and carbonization. Due to the lack of chain structures and/or molecular entanglements, an aqueous mixture 
Table 3: Summary of the conditions for the synthesis of CNFs by electrospinning.

\begin{tabular}{|c|c|c|c|c|c|c|}
\hline Polymer precursor ${ }^{\mathrm{a}}$ & Solvent ${ }^{b}$ & $\begin{array}{l}\text { Electrospinning } \\
\text { potential }\end{array}$ & Carbonization $\left({ }^{\circ} \mathrm{C}\right)$ & Diameter (nm) & Morphology & References \\
\hline PAN & DMF & $30 \mathrm{kV}$ & $1000-1200$ & 250 & Web & (Mao et al. 2013) \\
\hline PAN & DMF & $20 \mathrm{kV} \mathrm{DC}$ & 800 & $200-300$ & Web & (Shim et al. 2006) \\
\hline PAN & DMF & $25 \mathrm{kV}$ & $700-2800$ & $200-300$ & Web & (Kim et al. 2006) \\
\hline PAN & DMF & $25 \mathrm{kV}$ & 1000 & $100-200$ & Nonwoven web & (Wei et al. 2014) \\
\hline PAN & DMF & $18 \mathrm{kV}$ & 900 & 441 & $\begin{array}{l}\text { Aligned in one } \\
\text { direction }\end{array}$ & (Kim et al. 2016) \\
\hline PAN & DMSO & $60 \mathrm{kV}$ & 500 and 800 & 230 & Mat & $\begin{array}{l}\text { (Sabantina et al. } \\
\text { 2018) }\end{array}$ \\
\hline $\mathrm{PAN} / \mathrm{PVP} / \mathrm{TiCl}_{4}$ & DMF & $27 \mathrm{kV}$ & 1000 & 284 & Web & (Zhou et al. 2016a) \\
\hline $\mathrm{PAN} / \mathrm{CA}$ & DMF & $20 \mathrm{kV}$ & 1000 & $150-400$ & Web & (Ju and Oh 2017) \\
\hline $\mathrm{PAN} /$ pitch $/ \mathrm{MnCl}_{2}$ & $\mathrm{DMF} / \mathrm{THF}$ & - & 800 & - & Web & (Yang and Kim 2018) \\
\hline PAN & $\mathrm{DMF} / \mathrm{DMAC}$ & $12 \mathrm{kV}$ & 950 & 266 & Web & (Yuan et al. 2018) \\
\hline $\mathrm{PAN} / \mathrm{Ni}(\mathrm{OAC})_{2} / \mathrm{Co}(\mathrm{OAc})_{2}$ & DMF & $17 \mathrm{kV}$ & 900 & $250-300$ & Web & (Alegre et al. 2018) \\
\hline Pitch & $\mathrm{DMF} / \mathrm{THF}$ & $18-25 \mathrm{kV}$ & 600 & - & $\begin{array}{l}\text { Dumbbell-like } \\
\text { cross-section }\end{array}$ & $\begin{array}{l}\text { (Park et al. 2004, Yang } \\
\text { et al. 2014) }\end{array}$ \\
\hline Pls & $\mathrm{THF} / \mathrm{MeOH}$ & $13-15 \mathrm{kV}$ & $700-1000$ & $1000-2000$ & Webs & $\begin{array}{l}\text { (Yang et al. 2003, Kim } \\
\text { et al. 2004) }\end{array}$ \\
\hline Pls & DMF & $18 \mathrm{kV}$ & 900 & - & Web & (Zhang et al. 2018) \\
\hline PVA & Distilled water & $40 \mathrm{kV}$ & $600-1000$ & 693 & - & (Ju et al. 2017) \\
\hline \multirow[t]{2}{*}{ PAN/PMMA } & DMF & $18 \mathrm{kV}$ & 1000 & $100-300$ & Yarn & (Zhou et al. 2016b) \\
\hline & DMF & $15 \mathrm{kV}$ & 1000 & $197-260$ & Mats & (Abeykoon et al. 2015) \\
\hline \multicolumn{7}{|l|}{$\mathrm{MnCl}_{2}$} \\
\hline Lignin & $\begin{array}{l}\text { DMF } \\
\text { Water }\end{array}$ & $6-26 \mathrm{kV}$ & $600-1000$ & $400-1000$ & - & $\begin{array}{l}\text { (Ruiz-Rosas et al. } \\
\text { 2010) }\end{array}$ \\
\hline Lignin & Ethanol & $14 \mathrm{kV}$ & 900 & 600 & Web & $\begin{array}{l}\text { (García-Mateos et al. } \\
\text { 2017) }\end{array}$ \\
\hline Lignin $/ \mathrm{H}_{3} \mathrm{PO}_{4}$ & Ethanol & $24 \mathrm{kV}$ & 900 & 400 & Web & $\begin{array}{l}\text { (García-Mateos et al. } \\
\text { 2018) }\end{array}$ \\
\hline Alkali lignin/PVA & Water & $26 \mathrm{kV}$ & 1200 & $100-150$ & Mats & (Lai et al. 2014) \\
\hline Alkali lignin/PVA & Water & $26 \mathrm{kV}$ & 1200 & 200 & Membrane & (Beck et al. 2017) \\
\hline PVP/PANi/graphene & Water & $20 \mathrm{kV}$ & 1200 & $140-160$ & Fiber & (Al-Enizi et al. 2017) \\
\hline PVP/PMMA/ZrB & DMF & $12 \mathrm{kV}$ & 800 & 170 & Fiber & (Dai et al. 2017) \\
\hline $\mathrm{PVP} / \mathrm{Co}\left(\mathrm{NO}_{3}\right)_{2}$ & Water/ethanol & $15 \mathrm{kV}$ & 800 & 150 & Mat & (Fu et al. 2016) \\
\hline Coal/PAN & $\mathrm{DMF}$ & $17 \mathrm{kV}$ & 800 & - & Mat & (He et al. 2016) \\
\hline
\end{tabular}

aPAN, polyacrylonitrile; PMMA, poly(methyl methacrylate); PVP, polyvinylpyrrolidone; PVA, polyvinyl alcohol; PIs, polyimides; PANi, polyaniline; CA, cellulose acetate; ' $\mathrm{DMF}, \mathrm{N}, \mathrm{N}$-dimethylformamide; DMAc, $\mathrm{N}, \mathrm{N}$-dimethylacetamide; DMSO, dimethyl sulfoxide; THF, tetrahydrofuran; $\mathrm{MeOH}$, methanol.

containing alkali lignin alone could not be electrospun into nanofibers at any lignin concentration. The diameter of the lignin/PVA composite nanofibers decreased with increasing lignin amount.

Polyimide-based nanofibers have been produced by imidizing electrospun poly(amic acid) fibers followed by carbonization under a nitrogen atmosphere (Yang et al. 2003, Kim et al. 2004). PI-based CNFs show better mechanical strength compared with PAN-based CNFs (Cheng et al. 2009). On the other hand, core/shell nanofibers have been prepared from PMMA as a pyrolytic core and PAN as a carbon shell (Kaerkitcha et al. 2016).

\subsection{Templating}

A substantially less common pathway to obtain CNFs is by using templates. The templating synthesis of CNFs is based on the thermal decomposition of a carbon precursor in the nanometric channels of a film of anodic aluminum oxide (AAO). Then, the film is washed to dissolve the AAO and obtain the CNFs. Figure 5 shows an illustration of the process.

Table 4 summarizes some data concerning the synthesis of CNFs by templating. The fiber diameter is controlled by the size of the channels in the AAO, and other properties can be adjusted by the appropriate selection of 


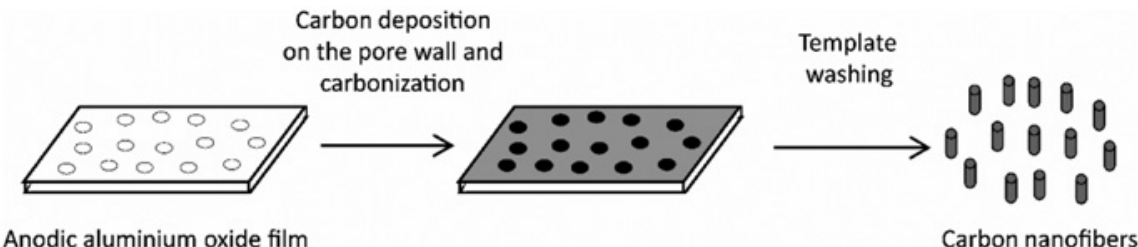

Figure 5: Schematic of CNF formation by templating.

Table 4: Summary of the conditions for the synthesis of CNFs by templating.

\begin{tabular}{|c|c|c|c|c|c|c|c|}
\hline CNF precursor & Solvent & Film & $\begin{array}{l}\text { Carbonization } \\
\text { temperature }\left({ }^{\circ} \mathrm{C}\right)\end{array}$ & $\begin{array}{l}\text { Washing } \\
\text { solution }\end{array}$ & Diameter (nm) & Morphology & References \\
\hline Propylene & None & AAO & 800 & $46 \%$ aqueous HF & 30 and 230 & Tubular & $\begin{array}{l}\text { (Kyotani et al. } \\
\text { 1995) }\end{array}$ \\
\hline $\begin{array}{l}\text { Pluronic F127/ } \\
\text { resol }\end{array}$ & Ethanol & AAO & 350 and 700 & $10 \%$ aqueous $\mathrm{HF}$ & 25 & $\begin{array}{l}\text { Nanofibers with linear } \\
\text { arrays of mesocages }\end{array}$ & $\begin{array}{l}\text { (Wang et al. } \\
\text { 2010) }\end{array}$ \\
\hline Phenolic resin & Ethanol & $\begin{array}{l}\text { AAO and colloidal } \\
\text { silica (porogen) }\end{array}$ & 700 & $\begin{array}{l}\mathrm{NaOH} 2 \mathrm{~m} \text { at } \\
80^{\circ} \mathrm{C}\end{array}$ & 240 & $\begin{array}{l}\text { Mesoporous hollow } \\
\text { tubular fibers }\end{array}$ & (Xing et al. 2014) \\
\hline
\end{tabular}

a carbon precursor, which can be a gas or liquid, and the carbonization temperature.

The CNFs obtained using this methodology have a length that corresponds with the thickness of the film, and the outer diameter is nearly the same as the channel diameter of the film. The fibers can also connect to one another at both ends of each fiber because the carbon deposition occurs on the outer surface of the anodic film (Kyotani et al. 1995). Unlike with the electrospinning method, in the templating methodology, the CNFs do not shrink totally during carbonization due to the close contact between the surface of the nanofibers and the pore wall of AAO (Zheng et al. 2009).

Several methods to introduce pores in the CNFs produced by templating have been reported. Wang et al. (2010) have synthesized mesoporous CNFs through evaporation. The inner mesocages are elongated in the transversal section with a pore size of approximately $18 \mathrm{~nm}$. Xing et al. (2014) have combined colloidal silica and AAO to obtain mesoporous CNFs. The nanofibers obtained are composed of open macroscale channels resulting from the AAO template containing open mesoporous ( $21 \mathrm{~nm}$ ) channels that developed during the removal of the colloidal silica and from the micropores that developed during the carbonization of the phenolic resin.

\subsection{Summary}

Carbon nanofibers are mainly synthesized in two different ways: CVD and electrospinning/carbonization.
In comparison, CVD generally produces CNFs with an inferior diameter. In most cases, the presented materials obtained by electrospinning are outside of the CNF size scale. In the literature, we can find other techniques using templates.

The different techniques have in common the ability to allow us to create CNFs with different properties. The processes are conditioned by several parameters that give freedom to the synthesis. The obtained CNFs are strongly dependent on the carbon precursor and the conditions of the reaction. In general, high temperatures, at more than $500^{\circ} \mathrm{C}$, are needed for the synthesis.

\section{Applications of CNFs}

\subsection{Catalytic support}

Carbon is an important support material in heterogeneous catalysis, in particular, for liquid-phase catalysis. The use of carbon materials is attractive because of the low cost when compared with that of precious metals (platinum, gold, etc.) (Serp and Figueiredo 2009).

The properties of the carbon support, such as surface area, pore volume, electrical and thermal conductivities, and corrosion resistance, strongly influence the performance of the catalyst, e.g. the activity, transport of electrons, heat dissipation, stability over time, and others (Serp et al. 2003). For CNFs, these characteristics mainly depend on the structure generated by the graphite plane 
stacks (Tsuji et al. 2007). The structure can be modified during the synthesis process by adequate choices of the reaction temperature and gas composition, as well as influenced by the natures of the precursor and catalyst used during the preparation of the CNFs (Rodriguez 1993, Serp et al. 2003), as discussed in the previous sections.

Several methodologies to synthesize CNF-supported platinum catalysts have been reported in the literature. There are numerous variations in some of the synthesis procedures that have received an extensive gamut of names in the literature, but all of them can be considered as variations of some basic methodologies with similar characteristics. Among them, the impregnation and microemulsion procedures have been reported for platinum deposition: impregnation and reduction with sodium borohydride (Lizcano-Valbuena et al. 2002); impregnation and reduction with formic acid (Salgado et al. 2004); a four-component water-in-oil microemulsion formed by $n$-heptane, water, a surfactant and a cosurfactant; and a three-component water-in-oil microemulsion (without cosurfactant), with $\mathrm{NaBH}_{4}$ as the reduction agent (Eriksson 2004).

The basic properties of catalysts prepared using the impregnation method are strongly affected by the microstructure, surface reactivity, and metal precursor (Román-Martínez et al. 1995). The main factors are the morphology and nanostructure of the support; these enable the production of well-dispersed nanoparticle catalysts. Pt nanoparticles can be deposited onto CNFs efficiently and homogeneously (Endo et al. 2003). The presence of surface oxygen groups on CNFs improves the metal precursor impregnation during the synthesis (Van Dam and Van Bekkum 1991) and induces electron transfer using their delocalized free electrons.

It has been reported that the use of dendrimers for nanoparticle synthesis and deposition on CNFs does not assure good distribution of the nanoparticles on the carbon support. Heat treatment of the catalysts results in an increase in the particle size as well as the formation of crystalline Ru oxides. However, oxide formation increases the intrinsic catalytic activity for methanol oxidation (Calderón et al. 2017). Whereas Calderón et al. (2016) have synthesized palladium-nickel nanoparticles supported on CNFs by mixing CNFs, $\mathrm{Na}_{2} \mathrm{PdCl}_{4}$, and $\mathrm{NiCl}_{2}$ in ultrapure water with sonication. This results in well-dispersed nanoparticles with few agglomerates.

Other methodologies have also been reported to produce desirable catalyst features according to the catalytic reaction in which the CNF-supported material participates. Mesoporous CNFs with large cage-like pores obtained using thermally treated electrospun fibers can act as a support for Pt, being able to load a large amount of catalyst ( $80 \%$ Pt) (Liu et al. 2014). Functionalized CNFs can serve as a catalyst support for Ni-Mo catalysts (resulting in the CNFs being coaxially coated by Ni-decorated $\mathrm{MoS}_{2}$ slabs) and used in the hydrogenation of heavy oil fractions. The catalytic activity depends on the length of the slabs (Pinilla et al. 2015). Cobalt catalysts supported on CNFs have been used in the Fischer-Tropsch process (Yu et al. 2006, Díaz et al. 2013). It has been observed that the support crystallinity and the pore radius have an influence on the metal dispersion and consequently on the product selectivity and catalyst deactivation (Díaz et al. 2013).

Carbon nanofibers incorporated with 20\% manganese oxide have been prepared using the electrospinning method for vanadium redox flow battery applications, yielding devices with a very high energy efficiency, state of charge, and range of discharge values (Di Blasi et al. 2017).

The synthesis of electrospun metal oxide-CNF composites as electrochemical catalysts has been previously reported (Busacca et al. 2017). Busacca et al. have prepared an urchin-like $\mathrm{V}_{2} \mathrm{O}_{3}$-CNF composite and pristine CNFs by electrospinning for a vanadium redox flow battery. They found the best electrocatalyst activity composite sample with a higher surface because of the number of active sites provided by the oxygen functional groups.

Yuan and Ryu (2004) have found that when CNFs are used as a Pt support for fuel cells, the reduction of the CNFs' diameter provides a better performance. In addition, twisted CNFs also present better activity compared with straight CNFs.

\subsection{Fuel cell systems}

Fuel cell technologies are considered to be interesting energy conversion devices to replace fossil fuel-based systems. In a fuel cell, the chemical energy of a fuel such as hydrogen is directly converted into electrical energy through electrochemical processes (Carrette et al. 2001, Hoogers 2003, Srinivasan 2006, Aricò et al. 2010).

Fuel cells are generally classified according to the type of electrolyte: alkaline fuel cells, polymer electrolyte fuel cells, phosphoric acid fuel cells, molten carbonate fuel cells, and solid oxide fuel cells (Hoogers 2003). On the other hand, polymer electrolyte fuel cells that use alcohols commonly receive a special name (direct methanol fuel cells or direct alcohol fuel cells) (Aricò et al. 2010). There is also a special type of fuel cell fed with carbon (direct carbon fuel cells) and based on a solid oxide electrolyte (Yu et al. 2016b). The proper choice of a fuel cell 
is a function of the application characteristics: power density, specific energy required, temperature, durability, response time, and others.

CNFs possess a mesoporous texture with a relatively large external surface area that can greatly reduce the inner pore diffusion resistance of reactants or products during catalytic reactions in fuel cells. The electrocatalysts, based on platinum supported on a carbon material, are responsible for this energy conversion electrochemical process.

The nature of CNFs used as an electrocatalyst support aids in improving the diffusion of reactants and products, contributes to the increase in the electrical conductivity, enhances the metal-support interaction, and improves the resistance to corrosion processes (Bessel et al. 2001). The support properties determine the catalyst's activity and durability, and we find that a compromise among the carbon order degree, the porous structure, and surface chemistry is mandatory.

When designing fuel cell electrodes for a certain power density it is important to use a high metal concentration in the catalyst ( $>20 \mathrm{wt} . \%$ ) to minimize the ohmic drop in the catalytic layer. The main drawback in the use of CNFs as a support for fuel cell catalysts is their relatively low surface area $\left(<200 \mathrm{~m}^{2} / \mathrm{g}\right)$, which makes it difficult to properly disperse a high concentration of noble-metal nanoparticles 2-3 mm in size (Kvande et al. 2007).

The method of noble-metal deposition on CNFs seems to be critical to achieving a good dispersion. In this context, the colloidal and microemulsion methods show the proper capability to produce catalysts with a mean $\mathrm{Pt}$ crystallite size of less than $3.5 \mathrm{~nm}$ (Sebastián et al. 2013b). A CNF support with a low Brunauer-Emmett-Teller (BET) surface area is prompted to mitigate carbon support corrosion in fuel cell applications. In addition, the mesoporous structure of CNFs seems relevant to reduce mass transport constraints. A volcano-shaped relationship has been observed for the oxygen reduction reaction mass activity as a function of the particle size for CNF-supported Pt nanoparticles, similar to what has been demonstrated by Kinoshita for carbon black-supported Pt catalysts (Sebastián et al. 2013b).

Another interesting application involves CNF-supported PtRu catalysts for the oxidation of alcohols in direct alcohol fuel cells. PtRu catalysts oxidize carbon monoxide (an oxidation intermediate) at a more negative potential compared with Pt catalysts (an approximately 0.1-0.2 V difference) due to the effect of ruthenium (favoring the adsorption of oxygen species that oxidize $\mathrm{CO}$ to $\mathrm{CO}_{2}$ ) (Aricò et al. 2010).

Sebastián et al. have investigated different CNFs as the support for platinum-ruthenium nanoparticles as a catalyst for the anodic electrochemical reaction of a direct alcohol fuel cell. Methanol oxidation is favored when supporting PtRu nanoparticles on highly graphitic CNFs. On the other hand, the highly graphitic nanofibers that improve the oxidation of methanol show a low activity toward the oxidation of ethanol. The pore volume is thus found to be important so that CNFs with greater porosity maximize the ethanol oxidation reaction activity, despite being less graphitic (Sebastián et al. 2013c).

Electrodes with a CNF layer could improve the performance of the direct methanol fuel cell due to several advantages: operation at a low concentration of methanol, operation at room temperature, low catalyst loading in the anode and cathode, and no parasitic load (Zainoodin et al. 2014).

The oxidation of CNFs also represents a significant increase in activity toward the electro-oxidation of methanol (Sebastián et al. 2014). The effect of oxidation treatments is not independent of the CNF properties and must be considered for a convenient support optimization. The optimum support is obtained when balancing three parameters: a sufficient electrochemical surface area, an improved metal-support interaction due to the effect of oxygen functionalities, and good methanol diffusion through the catalyst pores due to the wettability of oxidized CNFs (Sebastián et al. 2014).

\subsection{Hydrogen storage devices}

The purpose of hydrogen storage devices is to achieve the highest hydrogen volumetric density by packing the hydrogen molecules as closely as possible. From a theoretical point of view, thin CNFs are suitable candidates for $\mathrm{H}_{2}$ storage by adsorption due to their large surface area, pore microstructure and low-mass density (Niemann et al. 2008), as well as their chemical stability and the facile regeneration. There exist excellent reviews on nanostructured materials for energy storage (Aricò et al. 2005), including CNFs for hydrogen (Yürüm et al. 2009, Yu et al. 2017).

It is known that higher graphitic carbon materials adsorb less hydrogen compared with amorphous materials; therefore, the hydrogen storage capacity depends strongly on the structure. Jordá-Beneyto et al. (2007) have found that the hydrogen adsorption capacity at $298 \mathrm{~K}$ depends on both the micropore volume and the micropore size distribution. At $77 \mathrm{~K}$, hydrogen adsorption depends on the surface area and the total micropore volume of the carbon material. The experimental and theoretical predictions indicate that the key factor to high hydrogen 
adsorption capacity is the presence of a big volume of small open pores with a narrow size distribution (Jiménez et al. 2012). The optimum pore diameter for hydrogen adsorption is double that of the hydrogen molecule diameter (hydrogen diameter $=0.29 \mathrm{~nm}$, and optimum pore diameter $=0.6-0.7 \mathrm{~nm}$ ) (Rzepka et al. 1998).

Carbon nanofibers with graphene layers oriented perpendicularly or angularly to the fiber axis are the most efficient for the adsorption of hydrogen (Danilov et al. 2008). Jiménez et al. (2012) have observed that the hydrogen adsorption capacity, in general, is higher for CNFs with a higher BET surface area and for CNFs with a large number of accessible edge sites. Their results are collected in Table 5. They have also studied the effect of increasing the BET surface area by chemical activation with $\mathrm{KOH}$. In this case, the adsorption capacities are significantly higher than those of the nonactivated materials, as shown in Table 5.

It has been observed that when the hydrogen is produced in situ, it easily penetrates into the nonporous carbon, where it is adsorbed due to the driving force of the negative polarization. Hydrogen uptake thus has a strong dependence on the microporous volume and specific surface area of the prepared carbon materials (Armandi et al. 2008). Indeed, microporosity is an important factor that favors high hydrogen storage capacity because it generates more defective domains where hydrogen is preferably adsorbed (Lota et al. 2011).

Zhu et al. (2003) have found that CNFs with high graphitization, as well as the presence of exposed edges on the surface and the absence of oxygenated groups, are favorable for hydrogen adsorption. The hydrogen adsorption capacity strongly depends on the CNF pretreatment and hydrogen purity.

Hwang et al. (2002) have found that heat treatment enhanced the storage capacity of hydrogen. CNFs with a fishbone structure have a hydrogen uptake capacity of $1.1 \mathrm{wt} . \%$, whereas after a heat treatment at $1200^{\circ} \mathrm{C}$, the CNFs have an increased hydrogen uptake capacity up to
$1.4 \mathrm{wt} . \%$. The heat treatment increases the active surface for hydrogen adsorption by removing organic compounds blocking the surface. Moreover, Lianquan et al. have found that the modification of CNFs with some metals (Ni and $\mathrm{Cu}$ ) improves their ability to adsorb hydrogen (Lianquan et al. 2004, Danilov et al. 2008).

Electrospun CNFs obtained by an activation treatment can present multiple sites for the adsorption of hydrogen because of the porous structure derived from their surface and the controlled pore sizes. Kim et al. (2011) have synthesized uniform nanoporous CNFs with Pd nanoparticles using water vapor as a nanoscale pore former. The resulting material possesses $816-1121 \mathrm{~m}^{2} / \mathrm{g}$ and a hydrogen adsorption capacity of $2.3 \mathrm{wt} . \% \mathrm{H}_{2}$ at $-196^{\circ} \mathrm{C}$ and $0.82 \mathrm{wt} . \%$ at $25^{\circ} \mathrm{C}, 0.1 \mathrm{MPa}$.

Electrochemical hydrogen storage is a simpler alternative method, in which atomic hydrogen is adsorbed in hydrogen storage materials simultaneously during the electrolysis of an aqueous medium. Compared with conventional hydrogen storage using high pressure/low temperature, electrochemical hydrogen storage is more attractive because it occurs at room temperature and pressure (Xing et al. 2014). Additionally, in this case, the deposition of copper further improves the electrochemical hydrogen storage characteristics of CNFs (Danilov et al. 2008).

\subsection{Functional nanocomposites}

Currently, CNFs are used for reinforcing polymer matrices to improve their mechanical, thermal, and electrical properties. CNFs provide a tremendous interfacial area and decrease the size of possible defects thanks to their high aspect ratios and nanoscale diameters (Rana et al. 2011). Two different routes have mainly been investigated for the manufacture of these composites: the dispersion of nanomaterials within the matrix and the incorporation of nanomaterials on the surface of conventional fibers by

Table 5: Hydrogen adsorption capacity at a pressure of 10 bar for CNFs with different structures on the basis of the angle between the graphenic layers and the growth axis, based on the work of Jiménez et al. (2012).

\begin{tabular}{|c|c|c|c|c|c|c|}
\hline \multirow[t]{3}{*}{ Angle } & \multicolumn{2}{|c|}{ BET surface area $\left(\mathrm{m}^{2} / \mathrm{g}\right)$} & \multicolumn{4}{|c|}{$\mathrm{H}_{2}$ adsorption capacity (wt.\%) } \\
\hline & & & \multicolumn{2}{|r|}{$-196^{\circ} \mathrm{C}$} & \multicolumn{2}{|r|}{$26^{\circ} \mathrm{C}$} \\
\hline & Pristine & Activated & Pristine & Activated & Pristine & Activated \\
\hline $0^{\circ}-20^{\circ}$ & 68 & 310 & 0.11 & 0.51 & 0.02 & 0.03 \\
\hline $25^{\circ}-50^{\circ}$ & 202 & 570 & 0.34 & 1.00 & 0.03 & 0.04 \\
\hline $40^{\circ}-90^{\circ}$ & 286 & 786 & 0.49 & 2.22 & 0.03 & 0.05 \\
\hline
\end{tabular}


depositing, growing, or grafting prior to their use in composites (Bhattacharyya et al. 2013).

The properties and performance of the $\mathrm{CNF} /$ polymer composite strongly depend on the dispersion of the CNFs in the polymer matrix. Among the different dispersion techniques, the most used is melt mixing, but some other procedures and variations have been reported, such as those involving a roll mill, Haake torque rheometer, and mini-max molder (Feng et al. 2014).

CNFs, though not that perfect in structure compared with that of CNTs, have been demonstrated to have positive effects on the properties of polymer composites and to show promise for use in metal-matrix composites (Hammel et al. 2004). Moore et al. (2009) have indicated that to generate composites with a high thermal conductivity, CNFs can be incorporated in various polymer matrices to create more thermal-conductive paths. The carbon nanostructure highly influences the effect on the nanocomposite, as in the case of epoxy-based composites with carbon nanofilaments obtained from $\mathrm{Ni}$ or Fe: it has been observed that the electrical resistivity of the composite decreases to a large extent when using a certain amount of Fe-based CNFs (Suelves et al. 2013).

Some publications have reported on the improvement of mechanical properties by the incorporation of CNFs into functional nanocomposites. Vapor-grown CNFs have been dispersed homogeneously into a phenolic resin, and carbon fabrics are subsequently impregnated with the CNF-dispersed resin to develop carbon fiber/phenolic resin multiscale composites. The incorporation of 1.5 wt. $\%$ CNF results in the $10 \%$ improvement in Young's modulus, $12 \%$ increase in tensile strength, and $36 \%$ increase in thermal conductivity of the carbon/phenolic composite. Choi et al. (2005) have prepared epoxy/vaporgrown CNFs composites. The CNFs delayed the decomposition of the epoxy, whereas the maximum tensile strength and Young's modulus are obtained with 5 wt.\% of CNFs. Hammel et al. (2004) have synthesized polymer composites by the dispersion of CNF into polymer matrices using intensive shear forces via extrusion. The polypropylene resin with $15 \mathrm{wt} . \%$ of CNFs improves the Young's modulus of the polymer by $90 \%$.

\subsection{Electromagnetic microwave absorption}

Microwave-absorbing materials have found promising applications in military and commodity markets. Typically, composite materials containing magnetic metal particles such as ferrite, nickel, and zinc have been used as magnetic reducers of electromagnetic waves in conjunction with polymeric resins. Due to this method's use of magnetic additives with a high specific mass, a heavy piece of equipment is generated. Currently, carbon materials (carbon black, carbon fibers, CNTs, and CNFs) are a leading role in the investigation and application of microwave-absorbing materials due to their low specific mass. CNFs and CNTs are interesting because of their high aspect ratio, which results in high electromagnetic losses at low filler content along with reductions in thickness and weight (Li et al. 2012).

Tao et al. have synthesized Fe-C nanofibers by electrospinning and heating in an Ar atmosphere for microwave absorption tests. Fe gives the magnetic properties, and the carbon improves the oxidation resistance of Fe nanoparticles and reduces the density of the material. This combination shows good microwave absorption properties (reflection loss $<-10 \mathrm{~dB}$ ) from 2.2 to $13.2 \mathrm{GHz}$, which is a wide frequency range (Wang et al. 2014).

\subsection{Summary}

CNFs are utilized in several applications. Currently, researchers are trying to take advantage of their good properties to enhance known materials or to create new ones. Here, we expose some relevant applications of the CNFs. The CNFs have been applied to improve chemical processes, using these materials as a catalyst or catalyst support. CNFs have also been studied for green technologies such as fuel cells and the related necessity of hydrogen storage.

It seems that the exposure of edge carbon atoms on the surface of the nanofilaments aids in the adsorption of molecules such as hydrogen, thus, favoring the hydrogen storage capacity. With respect to the electron-donating properties of metals, the edges positively influence the metal-support interaction and thus enhance the catalytic activity of CNF-supported catalysts. In this regard, the fishbone and platelet morphologies represent the most promising choices.

At the same time, new materials are being created using CNFs in composites. These composites are excellent for tuning properties and coordinating the desirable properties of different materials.

\section{Concluding remarks}

Carbon nanofibers are theoretically and practically a promising material due to their high versatility. There are different 
methods to synthesize CNFs that lead to different physicochemical properties. Because of the synthesis's influence, the best route for CNF production will depend on the characteristics required of the CNFs in their future application.

Currently, the research related to CNFs is extensive, but it is also clearly not complete. CNFs are constantly being studied to find and improve all kinds of applications for this material. CNFs can be matched with several applications, in which their high graphitization and peculiar nanostructure, together with a high thermal/electrical conductivity and mechanical resistance, confer novel properties in energy- and materials-related fields. In this review, some of the most relevant uses of CNFs are mentioned. The performances of most materials based on CNFs are still being studied due to the expectation of better results.

Carbon nanofibers continue to substantially contribute to science, and this is clearly reflected in the number of publications that this material still generates, regarding both synthesis routes and promising applications.

Acknowledgments: The authors acknowledge the Ministry of Science, Innovation and University (MICINN) and FEDER for the financial support through the project SOLCARE (PCIN2015_222) and from the Aragon government to the Fuel Conversion Group. J.C. Ruiz acknowledges the Aragon government for his $\mathrm{PhD}$ grant. D. Sebastián also acknowledges MICINN for his Ramón y Cajal contract (RyC-2016-20944).

\section{References}

Abeykoon NC, Bonso JS, Ferraris JP. Supercapacitor performance of carbon nanofiber electrodes derived from immiscible PAN/ PMMA polymer blends. RSC Adv 2015; 5: 19865-19873.

Al-Enizi AM, Elzatahry AA, Abdullah AM, Vinu A, Iwai H, Al-Deyab SS. High electrocatalytic performance of nitrogen-doped carbon nanofiber-supported nickel oxide nanocomposite for methanol oxidation in alkaline medium. Appl Surf Sci 2017; 401: 306-313.

Alegre C, Modica E, Lo Vecchio C, Sebastián D, Lázaro MJ, Aricò AS, Baglio V. Carbon nanofibers as advanced Pd catalyst supports for the air electrode of alkaline metal-air batteries. Chempluschem 2015; 80: 1384-1388.

Alegre C, Modica E, Di Blasi A, Di Blasi O, Busacca C, Ferraro M, Aricò AS, Antonucci V, Baglioa V. NiCo-loaded carbon nanofibers obtained by electrospinning: bifunctional behavior as air electrodes. Renew Energy 2018; 125: 250-259.

Anderson PE, Rodriguez NM. Growth of graphite nanofibers from the decomposition of $\mathrm{CO} / \mathrm{H}_{2}$ over silica-supported iron-nickel particles. J Mater Res 1999; 14: 2912-2921.

Aricò AS, Bruce P, Scrosati B, Tarascon J-M, van Schalkwijk W. Nanostructured materials for advanced energy conversion and storage devices. Nat Mater 2005; 4: 366-377.
Aricò AS, Baglio V, Antonucci V. Direct methanol fuel cells. UK: Nova Science Publishers, Inc., 2010.

Armandi M, Bonelli B, Areán CO, Garrone E. Role of microporosity in hydrogen adsorption on templated nanoporous carbons. Microporous Mesoporous Mater 2008; 112: 411-418.

Ashok J, Reema S, Anjaneyulu C, Subrahmanyam M, Venugopal A. Methane decomposition catalysts for $\mathrm{CO}$-free hydrogen production. Rev Chem Eng 2010; 26: 29-39.

Avraham ES, Fleker O, Benisvy L, Oakes L, Pint CL, Nessim GD. Inducing porosity and growing carbon nanofibers in ferroin perchlorate: an example of morphological transitions in coordination complexes. J Solid State Chem 2017; 253: 21-28.

Bai Y, Zhang R, Ye X, Zhu Z, Xie H, Shen B, Cai D, Liu B, Zhang C, Jia Z, Zhang S, Li X, Wei F. Carbon nanotube bundles with tensile strength over $80 \mathrm{GPa}$. Nat Nanotechnol 2018; 13: 589-595.

Baker RTK. Catalytic growth of carbon filaments. Carbon N Y 1989; 27: 315-323.

Baker RTK, Harris PS, Thomas RB, Waite RJ. Formation of filamentous carbon from iron, cobalt and chromium catalyzed decomposition of acetylene. J Catal 1973; 30: 86-95.

Beck RJ, Zhao Y, Fong H, Menkhaus TJ. Electrospun lignin carbon nanofiber membranes with large pores for highly efficient adsorptive water treatment applications. J Water Process Eng 2017; 16: 240-248.

Bessel CA, Laubernds K, Rodriguez NM, Baker RTK. Graphite nanofibers as an electrode for fuel cell applications. J Phys Chem B 2001; 105: 1121-1122.

Bhattacharyya A, Rana S, Parveen S, Fangueiro R, Alagirusamy $R$, Joshi M. Mechanical and thermal transmission properties of carbon nanofiber-dispersed carbon/phenolic multiscale composites. J Appl Polym Sci 2013; 129: 2383-2392.

Bognitzki M, Czado W, Frese T, Schaper A, Hellwig M, Steinhart M, Greiner A, Wendorff JH. Nanostructured fibers via electrospinning. Adv Mater 2001; 13: 70-72.

Busacca C, Di Blasi O, Briguglio N, Ferraro M, Antonucci V, Di Blasi A. Electrochemical performance investigation of electrospun urchin-like $\mathrm{V}_{2} \mathrm{O}_{3}$-CNF composite nanostructure for vanadium redox flow battery. Electrochim Acta 2017; 230: 174-180.

Calderón J, Rios Ráfales M, Nieto-Monge M, Pardo J, Moliner R, Lázaro M. Oxidation of $\mathrm{CO}$ and methanol on Pd-Ni catalysts supported on different chemically-treated carbon nanofibers. Nanomaterials 2016; 6: 187.

Calderón J, Calvillo L, Lázaro M, Rodríguez J, Pastor E. Effect of the dendrimer generation used in the synthesis of Pt-Ru nanoparticles supported on carbon nanofibers on the catalytic activity towards methanol oxidation. Energies 2017; 10: 159.

Cameán I, García AB, Suelves I, Pinilla JL, Lázaro MJ, Moliner R, Rouzaud J-N. Influence of the inherent metal species on the graphitization of methane-based carbon nanofibers. Carbon $\mathrm{N}$ Y 2012; 50: 5387-5394.

Carrette L, Friedrich KA, Stimming U. Fuel cells - fundamentals and applications. Fuel Cells 2001; 1: 5-39.

Chen D, Christensen KO, Ochoa-Fernández E, Yu Z, Tøtdal B, Latorre $\mathrm{N}$, Monzón A, Holmen A. Synthesis of carbon nanofibers: effects of Ni crystal size during methane decomposition. J Catal 2005; 229: 82-96.

Cheng S, Shen D, Zhu X, Tian X, Zhou D, Fan L-J. Preparation of nonwoven polyimide/silica hybrid nanofiberous fabrics by combining electrospinning and controlled in situ sol-gel techniques. Eur Polym J 2009; 45: 2767-2778. 
Choi Y-K, Sugimoto K, Song S-M, Gotoh Y, Ohkoshi Y, Endo M. Mechanical and physical properties of epoxy composites reinforced by vapor grown carbon nanofibers. Carbon N Y 2005; 43: 2199-2208.

Dai Y, Zhu G, Shang X, Zhu T, Yang J, Liu J. Electrospun zirconiaembedded carbon nanofibre for high-sensitive determination of methyl parathion. Electrochem Commun 2017; 81: 14-17.

Danilov MO, Melezhyk AV, Kolbasov GY. Carbon nanofibers as hydrogen adsorbing materials for power sources. J Power Sources 2008; 176: 320-324.

De Jong KP, Geus JW. Carbon nanofibers: catalytic synthesis and applications. Catal Rev - Sci Eng 2000; 42: 481-510.

Di Blasi A, Busaccaa C, Di Blasia O, Briguglioa N, Squadritoa $\mathrm{G}$, Antonuccia V. Synthesis of flexible electrodes based on electrospun carbon nanofibers with $\mathrm{Mn}_{3} \mathrm{O}_{4}$ nanoparticles for vanadium redox flow battery application. Appl Energy 2017; 190: 165-171.

Díaz JA, Martínez-Fernández M, Romero A, Valverde JL. Synthesis of carbon nanofibers supported cobalt catalysts for FischerTropsch process. Fuel 2013; 111: 422-429.

Doshi J, Reneker DH. Electrospinning process and applications of electrospun fibers. J Electrostat 1995; 35: 151-160.

Endo M, Kim YA, Ezaka M, Osada K, Yanagisawa T, Hayashi $T$, Terrones M, Dresselhaus MS. Selective and efficient impregnation of metal nanoparticles on cup-stacked-type carbon nanofibers. Nano Lett 2003; 3: 723-726.

Eriksson S. Preparation of catalysts from microemulsions and their applications in heterogeneous catalysis. Appl Catal A Gen 2004; 265: 207-219.

Feng L, Xie N, Zhong J. Carbon nanofibers and their composites: a review of synthesizing, properties and applications. Vol. 7, Materials. Multidisciplinary Digital Publishing Institute, 2014: 3919-3945.

Figueiredo JL, Bernardo CA, Baker RTK, Hüttinger KJ, editors. Carbon fibers filaments and composites. Dordrecht: Springer Netherlands, 1990.

$\mathrm{Fu} \mathrm{B}$, Zhou X, Wang Y. $\mathrm{Co}_{3} \mathrm{O}_{4}$ carbon nanofiber mats as negative electrodes for sodium-ion batteries. Mater Lett 2016; 170: 21-24.

Garcia AB, Cameán I, Suelves I, Pinilla JL, Lázaro MJ, Palacios JM, Moliner R. The graphitization of carbon nanofibers produced by the catalytic decomposition of natural gas. Carbon N Y 2009; 47: 2563-2570.

Garcia AB, Cameán I, Pinilla JL, Suelves I, Lázaro MJ, Moliner R. The graphitization of carbon nanofibers produced by catalytic decomposition of methane: synergetic effect of the inherent $\mathrm{Ni}$ and Si. Fuel 2010; 89: 2160-2162.

García-Mateos FJ, Cordero-Lanzac T, Berenguer R, Morallón E, CazorlaAmorós D, Rodríguez-Mirasol J, Cordero T. Lignin-derived Pt supported carbon (submicron) fiber electrocatalysts for alcohol electro-oxidation. Appl Catal B Environ 2017; 211: 18-30.

García-Mateos FJ, Berenguer R, Valero-Romero MJ, RodríguezMirasol J, Cordero T. Phosphorus functionalization for the rapid preparation of highly nanoporous submicron-diameter carbon fibers by electrospinning of lignin solutions. J Mater Chem A 2018; 6: 1219-1333.

Guo Q, Zhou X, Li X, Chen S, Seema A, Greiner A, Hou H. Supercapacitors based on hybrid carbon nanofibers containing multiwalled carbon nanotubes. J Mater Chem 2009; 19: 2810.

Hammel E, Tang X, Trampert M, Schmitt T, Mauthner K, Eder A, Pötschke P. Carbon nanofibers for composite applications. Carbon N Y 2004; 42: 1153-1158.
He Z, Maurice J-L, Gohier A, Lee CS, Pribat D, Cojocaru CS. Iron catalysts for the growth of carbon nanofibers: $\mathrm{Fe}, \mathrm{Fe}_{3} \mathrm{C}$ or both? Chem Mater 2011; 23: 5379-5387.

He Y, Wang L, Jia D. Coal/PAN interconnected carbon nanofibers with excellent energy storage performance and electrical conductivity. Electrochim Acta 2016; 194: 239-245.

Helveg S, López-Cartes C, Sehested J, Hansen PL, Clausen BS, Rostrup-Nielsen JR, Abild-Pedersen F, Nørskov JK. Atomic-scale imaging of carbon nanofibre growth. Nature 2004; 427 : 426-429.

Hoogers G. Fuel cell technology handbook. CRC Press, 2003.

Hwang JY, Lee SH, Sim KS, Kim JW. Synthesis and hydrogen storage of carbon nanofibers. Synth Met 2002; 126: 81-85.

Hyun Y, Choi J-Y, Park H-K, Lee C-S. Synthesis and electrochemical performance of ruthenium oxide-coated carbon nanofibers as anode materials for lithium secondary batteries. Appl Surf Sci 2016; 388: 274-280.

Inagaki M, Yang Y, Kang F. Carbon nanofibers prepared via electrospinning. Adv Mater 2012; 24: 2547-2566.

Jaworski Z, Zakrzewska B, Pianko-Oprych P. On thermodynamic equilibrium of carbon deposition from gaseous $\mathrm{C}-\mathrm{H}-\mathrm{O}$ mixtures: updating for nanotubes. Rev Chem Eng 2017; 33: 217-235.

Jeong JH, Kim B-H. Synergistic effects of pitch and poly(methyl methacrylate) on the morphological and capacitive properties of $\mathrm{MnO}_{2}$ / carbon nanofiber composites. J Electroanal Chem 2018; 809: 130-135.

Jiao J, Nolan PE, Seraphin S, Cutler AH, Lynch DC. Morphology of carbon nanoclusters prepared by catalytic disproportionation of carbon monoxide. J Electrochem Soc 1996; 143: 932.

Jiménez V, Ramírez-Lucas A, Sánchez P, Valverde JL, Romero A. Hydrogen storage in different carbon materials: influence of the porosity development by chemical activation. Appl Surf Sci 2012; 258: 2498-2509.

Jordá-Beneyto M, Suárez-García F, Lozano-Castelló D, CazorlaAmorós D, Linares-Solano A. Hydrogen storage on chemically activated carbons and carbon nanomaterials at high pressures. Carbon N Y 2007; 45: 293-303.

Ju Y-W, Oh G-Y. Behavior of toluene adsorption on activated carbon nanofibers prepared by electrospinning of a polyacrylonitrilecellulose acetate blending solution. Korean J Chem Eng 2017; 34: 2731-2737.

Ju J, Kang W, Deng N, Li L, Zhao Y, Ma X, Fan L, Cheng B. Preparation and characterization of PVA-based carbon nanofibers with honeycomb-like porous structure via electro-blown spinning method. Microporous Mesoporous Mater 2017; 239: 416-425.

Kaerkitcha N, Chuangchote S, Sagawa T. Control of physical properties of carbon nanofibers obtained from coaxial electrospinning of PMMA and PAN with adjustable inner/outer nozzle-ends. Nanoscale Res Lett 2016; 11: 186.

Kenzhin RM, Bauman YI, Volodin AM, Mishakov IV, Vedyagin AA. Synthesis of carbon nanofibers by catalytic CVD of chlorobenzene over bulk nickel alloy. Appl Surf Sci 2018; 427: 505-510.

Kim C, Choi Y-0, Lee W-J, Yang K-S. Supercapacitor performances of activated carbon fiber webs prepared by electrospinning of PMDA-ODA poly(amic acid) solutions. Electrochim Acta 2004; 50: 883-887.

Kim C, Yang KS, Kojima M, Yoshida K, Kim YJ, Kim YA, Kim YA, Endo $M$. Fabrication of electrospinning-derived carbon nanofiber webs for the anode material of lithium-ion secondary batteries. Adv Funct Mater 2006; 16: 2393-2397. 
Kim H, Lee D, Moon J. Co-electrospun Pd-coated porous carbon nanofibers for hydrogen storage applications. Int J Hydrog Energy 2011; 36: 3566-3573.

Kim M, Kim Y, Lee KM, Jeong SY, Lee E, Baeck SH, Shim SE. Electrochemical improvement due to alignment of carbon nanofibers fabricated by electrospinning as an electrode for supercapacitor. Carbon N Y 2016; 99: 607-618.

Kinoshita K. Carbon: electrochemical and physicochemical properties. New York: Wiley, 1988.

Kubo S, Kadla JF. Lignin-based carbon fibers: effect of synthetic polymer blending on fiber properties. J Polym Environ 2005; 13 : 97-105.

Kvande I, Briskeby ST, Tsypkin M, Rønning M, Sunde S, Tunold R, Chen D. On the preparation methods for carbon nanofibersupported Pt catalysts. Top Catal 2007; 45: 81-85.

Kyotani T, Tsai L, Tomita A. Formation of ultrafine carbon tubes by using an anodic aluminum oxide film as a template. Chem Mater 1995; 7: 1427-1428.

Lai C, Zhou Z, Zhang L, Wang X, Zhou Q, Zhao Y, Wang Y, Wu X-F, Zhu Z, Fong $\mathrm{H}$. Free-standing and mechanically flexible mats consisting of electrospun carbon nanofibers made from a natural product of alkali lignin as binder-free electrodes for high-performance supercapacitors. J Power Sources 2014; 247: 134-141.

Lamber R, Jaeger N, Schulz-Ekloff G. Electron microscopy study of the interaction of Ni, Pd and Pt with carbon. Surf Sci 1988; 197: 402-414.

Li P, Li T, Zhou J-H, Sui Z-J, Dai Y-C, Yuan W-K, Chen D. Synthesis of carbon nanofiber/graphite-felt composite as a catalyst. Microporous Mesoporous Mater 2006; 95: 1-7.

Li G, Xie T, Yang S, Jin J, Jiang J. Microwave absorption enhancement of porous carbon fibers compared with carbon nanofibers. J Phys Chem C 2012; 116: 9196-9201.

Li M, Carter R, Cohn AP, Pint CL. Interconnected foams of helical carbon nanofibers grown with ultrahigh yield for high capacity sodium ion battery anodes. Carbon N Y 2016a; 107: 109-115.

Li M, Li N, Shao W, Zhou C. Synthesis of carbon nanofibers by CVD as a catalyst support material using atomically ordered $\mathrm{Ni}_{3} \mathrm{C}$ nanoparticles. Carbon N Y 2016b; 40: 445503.

Lianquan G, Changxiang M, Yujie Z, Shuai W. Electrochemical study on hydrogen storage property of CNTs. J Northeast Univ Sci 2004; 25: 427-430.

Lim S, Shimizu A, Yoon S-H, Korai Y, Mochida I. High yield preparation of tubular carbon nanofibers over supported Co-Mo catalysts. Carbon N Y 2004; 42: 1279-1283.

Liu Z, Fu D, Liu F, Han G, Liu C, Chang Y, Xiao Y, Li M, Li S. Mesoporous carbon nanofibers with large cage-like pores activated by tin dioxide and their use in supercapacitor and catalyst support. Carbon N Y 2014; 70: 295-307.

Lizcano-Valbuena WH, Paganin VA, Gonzalez ER. Methanol electrooxidation on gas diffusion electrodes prepared with Pt-Ru/C catalysts. Electrochim Acta 2002; 47: 3715-3722.

Lobo LS. Nucleation and growth of carbon nanotubes and nanofibers: mechanism and catalytic geometry control. Carbon N Y 2017; 114: 411-417.

Lota G, Fic K, Frackowiak E. Carbon nanotubes and their composites in electrochemical applications. Energy Environ Sci 2011; 4: 1592.

Ma C, Song Y, Shi J, Zhang D, Zhai X, Zhong M, Guo Q, Liu L. Preparation and one-step activation of microporous carbon nanofibers for use as supercapacitor electrodes. Carbon N Y 2013; 51: 290-300.
Mao X, Simeon F, Rutledge GC, Hatton TA. Electrospun carbon nanofiber webs with controlled density of states for sensor applications. Adv Mater 2013; 25: 1309-1314.

Martin-Gullon I, Vera J, Conesa JA, González JL, Merino C. Differences between carbon nanofibers produced using $\mathrm{Fe}$ and $\mathrm{Ni}$ catalysts in a floating catalyst reactor. Carbon N Y 2006; 44: 1572-1580.

Megelski S, Stephens JS, Bruce Chase D, Rabolt JF. Micro- and nanostructured surface morphology on electrospun polymer fibers. Macromolecules 2002; 35: 8456-8466.

Moore AL, Cummings AT, Jensen JM, Shi L, Koo JH. Thermal conductivity measurements of nylon 11-carbon nanofiber nanocomposites. J Heat Transfer 2009; 131: 091602.

Mordkovich VZ. Carbon nanofibers: a new ultrahigh-strength material for chemical technology. Theor Found Chem Eng 2003; 37: 429-438.

Niemann MU, Srinivasan SS, Phani AR, Kumar A, Goswami DY, Stefanakos EK. Nanomaterials for hydrogen storage applications: a review. J Nanomater 2008; 2008: 1-9.

Nishiyama Y, Tamai Y. Carbon formation on copper-nickel alloys from benzene. J Catal 1974; 33: 98-107.

Ngo Q, Yamada T, Suzuki M, Ominami Y, Cassell AM, Li Jun, Meyyappan M, Yang CY. Structural and electrical characterization of carbon nanofibers for interconnect via applications. IEEE Trans Nanotechnol 2007; 6: 688-695.

Nolan PE, Lynch DC, Cutler AH. Carbon deposition and hydrocarbon formation on group VIII metal catalysts. J Phys Chem B 1998; 102: 4165-4175.

Ozkan T, Naraghi M, Chasiotis I. Mechanical properties of vapor grown carbon nanofibers. Carbon N Y 2010; 48: 239-244.

Pandolfo AG, Hollenkamp AF. Carbon properties and their role in supercapacitors. J Power Sources 2006; 157: 11-27.

Park SH, Kim C, Yang KS. Preparation of carbonized fiber web from electrospinning of isotropic pitch. Synth Met 2004; 143: 175-179.

Pinilla J, Suelves I, Lázaro M, Moliner R, Palacios J. Activity of $\mathrm{NiCuAl}$ catalyst in methane decomposition studied using a thermobalance and the structural changes in the $\mathrm{Ni}$ and the deposited carbon. Int J Hydrog Energy 2008; 33: 2515-2524.

Pinilla JL, Suelves I, Lázaro MJ, Moliner R, Palacios JM. Influence of nickel crystal domain size on the behaviour of $\mathrm{Ni}$ and $\mathrm{NiCu}$ catalysts for the methane decomposition reaction. Appl Catal A Gen 2009; 363: 199-207.

Pinilla JL, Lázaro MJ, Suelves I, Moliner R. Formation of hydrogen and filamentous carbon over a Ni-Cu- $\mathrm{Al}_{2} \mathrm{O}_{3}$ catalyst through ethane decomposition. Appl Catal A Gen 2011a; 394: 220-227.

Pinilla JL, Utrilla R, Karn RK, Suelves I, Lázaro MJ, Moliner R, García $A B$, Rouzaud JN. High temperature iron-based catalysts for hydrogen and nanostructured carbon production by methane decomposition. Int J Hydrog Energy 2011b; 36: 7832-7843.

Pinilla JL, Purón H, Torres D, Suelves I, Millan M. Ni-MoS 2 supported on carbon nanofibers as hydrogenation catalysts: effect of support functionalisation. Carbon N Y 2015; 81: 574-586.

Ra EJ, Raymundo-Piñero E, Lee YH, Béguin F. High power supercapacitors using polyacrylonitrile-based carbon nanofiber paper. Carbon N Y 2009; 47: 2984-2992.

Rahaman MSA, Ismail AF, Mustafa A. A review of heat treatment on polyacrylonitrile fiber. Polym Degrad Stab 2007; 92: 1421-1432.

Ramos A, Cameán I, García AB. Graphitization thermal treatment of carbon nanofibers. Carbon N Y 2013; 59: 2-32. 
Rana S, Alagirusamy R, Joshi M. Effect of carbon nanofiber dispersion on the tensile properties of epoxy nanocomposites. J Compos Mater 2011; 45: 2247-2256.

Reneker DH, Chun I. Nanometre diameter fibres of polymer, produced by electrospinning. Nanotechnology 1996; 7: 216-223.

Rodriguez NM. Review of catalytically grown carbon nanofibers. J Mater Res 1993; 8: 3233-3250.

Román-Martínez MC, Cazorla-Amorós D, Linares-Solano A, De Lecea CSM, Yamashita H, Anpo M. Metal-support interaction in Pt/C catalysts. Influence of the support surface chemistry and the metal precursor. Carbon N Y 1995; 33: 3-13.

Ruiz-Rosas R, Bedia J, Lallave M, Loscertales IG, Barrero A, Rodríguez-Mirasol J, Cordero T. The production of submicron diameter carbon fibers by the electrospinning of lignin. Carbon N Y 2010; 48: 696-705.

Rzepka M, Lamp P, de la Casa-Lillo MA. Physisorption of hydrogen on microporous carbon and carbon nanotubes. J Phys Chem B 1998; 102: 10894-10898.

Sabantina L, Rodríguez-Cano M, Klöcker M, García-Mateos F, Ternero-Hidalgo J, Mamun A, Beermann F, Schwakenberg M, Voigt A-L, Rodríguez-Mirasol J, Cordero T, Ehrmann A. Fixing PAN nanofiber mats during stabilization for carbonization and creating novel metal/carbon composites. Polymers (Basel) 2018; 10: 735.

Salgado JRC, Antolini E, Gonzalez ER. Structure and activity of carbon-supported Pt-Co electrocatalysts for oxygen reduction. J Phys Chem B 2004; 108: 17767-17774.

Sebastián D, Suelves I, Lázaro MJ, Moliner R. Carbon nanofibers as electrocatalyst support for fuel cells: effect of hydrogen on their properties in $\mathrm{CH}_{4}$ decomposition. J Power Sources 2009; 192: 51-56.

Sebastián D, Suelves I, Moliner R, Lázaro MJJ. The effect of the functionalization of carbon nanofibers on their electronic conductivity. Carbon N Y 2010; 48: 4421-4431.

Sebastián D, Suelves I, Moliner R, Lázaro MJ. Carbon nanofibers. In: Nanofibers: synthesis, properties, and applications. UK: Nova Science Publishers, Inc., 2012: 1-40.

Sebastián D, Ruiz AG, Suelves I, Moliner R, Lázaro MJ. On the importance of the structure in the electrical conductivity of fishbone carbon nanofibers. J Mater Sci 2013a; 48: 1423-1435.

Sebastián D, Suelves I, Moliner R, Lázaro MJMJ, Stassi A, Baglio V, Aricò AS. Optimizing the synthesis of carbon nanofiber based electrocatalysts for fuel cells. Appl Catal B Environ 2013b; 132-133: 22-27.

Sebastián D, Suelves I, Pastor E, Moliner R, Lázaro MJMJ. The effect of carbon nanofiber properties as support for PtRu nanoparticles on the electrooxidation of alcohols. Appl Catal B Environ 2013c; 132-133: 13-21.

Sebastián D, Lázaro MJJ, Moliner R, Suelves I, Aricò ASS, Baglio V. Oxidized carbon nanofibers supporting PtRu nanoparticles for direct methanol fuel cells. Int J Hydrog Energy 2014; 39: 5414-5423.

Serp P, Figueiredo JL. Carbon materials for catalysis. USA: John Wiley \& Sons, 2009.

Serp P, Corrias M, Kalck P. Carbon nanotubes and nanofibers in catalysis. Appl Catal A Gen 2003; 253: 337-358.

Shim WG, Kim C, Lee JW, Yun JJ, Jeong Y Il, Moon H, Yang KS. Adsorption characteristics of benzene on electrospun-derived porous carbon nanofibers. J Appl Polym Sci 2006; 102: 2454-2462.
Song H, Shen W. Carbon nanofibers: synthesis and applications. J Nanosci Nanotechnol 2014; 14: 1799-1810.

Sridhar D, Omanovic S, Meunier J-L. Direct growth of carbon nanofiber forest on nickel foam without any external catalyst. Diam Relat Mater 2018; 81: 70-76.

Srinivasan S. Fuel cells: from fundamentals to applications. USA: Springer, 2006.

Suelves I, Utrilla R, Torres D, De Llobet S, Pinilla JL, Lázaro MJ, Moliner R. Preparation of polymer composites using nanostructured carbon produced at large scale by catalytic decomposition of methane. Mater Chem Phys 2013; 137: 859-865.

Talreja N, Verma N, Kumar D. Carbon bead-supported ethylene diamine-functionalized carbon nanofibers: an efficient adsorbent for salicylic acid. CLEAN - Soil, Air, Water 2016; 44: 1461-1470.

Tanaka A, Yoon S-H, Mochida I. Formation of fine Fe-Ni particles for the non-supported catalytic synthesis of uniform carbon nanofibers. Carbon N Y 2004a; 42: 1291-1298.

Tanaka A, Yoon S-H, Mochida I. Preparation of highly crystalline nanofibers on $\mathrm{Fe}$ and $\mathrm{Fe}-\mathrm{Ni}$ catalysts with a variety of graphene plane alignments. Carbon N Y 2004b; 42: 591-597.

Toebes ML, Bitter JH, van Dillen AJ, de Jong KP. Impact of the structure and reactivity of nickel particles on the catalytic growth of carbon nanofibers. Catal Today 2002; 76: 33-42.

Torres D, De Llobet S, Pinilla JL, Lázaro MJ, Suelves I, Moliner R. Hydrogen production by catalytic decomposition of methane using a Fe-based catalyst in a fluidized bed reactor. J Nat Gas Chem 2012; 21: 367-373.

Torres D, Pinilla JL, Lázaro MJ, Moliner R, Suelves I. Hydrogen and multiwall carbon nanotubes production by catalytic decomposition of methane: thermogravimetric analysis and scaling-up of Fe-Mo catalysts. Int J Hydrog Energy 2014; 39: 3698-3709.

Tsuji M, Kubokawa M, Yano R, Miyamae N, Tsuji T, Jun M-S, Hong S, Lim S, Yoon S-H, Mochida I. Fast preparation of PtRu catalysts supported on carbon nanofibers by the microwave-polyol method and their application to fuel cells. Langmuir 2007; 23: 387-390.

Van Dam HE, Van Bekkum H. Preparation of platinum on activated carbon. J Catal 1991; 131: 335-349.

Vera-Agullo J, Varela-Rizo H, Conesa JA, Almansa C, Merino C, Martin-Gullon I. Evidence for growth mechanism and helix-spiral cone structure of stacked-cup carbon nanofibers. Carbon N Y 2007; 45: 2751-2758.

Wang Y, Zheng M, Lu H, Feng S, Ji G, Cao J. Template synthesis of carbon nanofibers containing linear mesocage arrays. Nanoscale Res Lett 2010; 5: 913-916.

Wang T, Wang H, Chi X, Li R, Wang J. Synthesis and microwave absorption properties of $\mathrm{Fe}-\mathrm{C}$ nanofibers by electrospinning with disperse Fe nanoparticles parceled by carbon. Carbon N Y 2014; 74: 312-318.

Wei G, Fan X, Liu J, Yan C. Investigation of the electrospun carbon web as the catalyst layer for vanadium redox flow battery. J Power Sources 2014; 270: 634-645.

Xing Y, Fang B, Bonakdarpour A, Zhang S, Wilkinson DP. Facile fabrication of mesoporous carbon nanofibers with unique hierarchical nanoarchitecture for electrochemical hydrogen storage. Int J Hydrog Energy 2014; 39: 7859-7867.

Xu B, Wu F, Chen R, Cao G, Chen S, Yang Y. Mesoporous activated carbon fiber as electrode material for high-performance 
electrochemical double layer capacitors with ionic liquid electrolyte. J Power Sources 2010; 195: 2118-2124.

Yang C-M, Kim B-H. Highly conductive pitch-based carbon nanofiber $/ \mathrm{MnO}_{2}$ composites for high-capacitance supercapacitors. J Alloys Compd 2018; 749: 441-447.

Yang KS, Edie DD, Lim DY, Kim YM, Choi YO. Preparation of carbon fiber web from electrostatic spinning of PMDA-ODA poly(amic acid) solution. Carbon N Y 2003; 41: 2039-2046.

Yang Y, Centrone A, Chen L, Simeon F, Alan Hatton T, Rutledge GC. Highly porous electrospun polyvinylidene fluoride (PVDF)-based carbon fiber. Carbon N Y 2011; 49: 3395-3403.

Yang KS, Kim B-H, Yoon S-H. Pitch based carbon fibers for automotive body and electrodes. Carbon Lett 2014; 15: 162-170.

Yu Z. Effect of support and reactant on the yield and structure of carbon growth by chemical vapour deposition. J Phys Chem B 2005; 109: 6096-6102.

Yu Z, Borg $\emptyset$, Chen D, Enger BC, Frøseth V, Rytter E, Wigum H, Holmen A. Carbon nanofiber supported cobalt catalysts for Fischer-Tropsch synthesis with high activity and selectivity. Catal Lett 2006; 109: 43-47.

Yu B, Zhang Q, Hou L, Wang S, Song M, He Y, Huang H, Zou J. Temperature-dependent chemical state of the nickel catalyst for the growth of carbon nanofibers. Carbon N Y 2016a; 96: 904-910.

Yu F, Zhang Y, Yu L, Cai W, Yuan L, Liu J, Liu M. All-solid-state direct carbon fuel cells with thin yttrium-stabilized-zirconia electrolyte supported on nickel and iron bimetal-based anodes. Int J Hydrog Energy 2016b; 41: 9048-9058.

Yu X, Tang Z, Sun D, Ouyang L, Zhu M. Recent advances and remaining challenges of nanostructured materials for hydrogen storage applications. Vol. 88, Pergamon: Progress in Materials Science, 2017: 1-48.

Yuan F, Ryu H. The synthesis, characterization, and performance of carbon nanotubes and carbon nanofibres with controlled size and morphology as a catalyst support material for a polymer electrolyte membrane fuel cell. Nanotechnology 2004; 15 : S596-602.

Yuan Z, Cheng X, Zhong L, Wu R, Zheng Y. Preparation, characterization and performance of an electrospun carbon nanofiber mat applied in hexavalent chromium removal from aqueous solution. J Environ Sci 2018 (in press).

Yürüm Y, Taralp A, Veziroglu TN. Storage of hydrogen in nanostructured carbon materials. Vol. 34, Pergamon: International Journal of Hydrogen Energy, 2009: 3784-3798.

Zainoodin AM, Kamarudin SK, Masdar MS, Daud WRW, Mohamad $A B$, Sahari J. High power direct methanol fuel cell with a porous carbon nanofiber anode layer. Appl Energy 2014; 113: 946-954.

Zhang R, Zhang Y, Zhang Q, Xie H, Qian W, Wei F. Growth of half-meter long carbon nanotubes based on Schulz-Flory distribution. ACS Nano 2013; 7: 6156-6161.

Zhang L, Aboagye A, Kelkar A, Lai C, Fong H. A review: carbon nanofibers from electrospun polyacrylonitrile and their applications. J Mater Sci 2014; 49: 463-480.

Zhang Y, Ou H, Liu H, Ke Y, Zhang W, Liao G, Wang D. Polyimide-based carbon nanofibers: a versatile adsorbent for highly efficient removals of chlorophenols, dyes and antibiotics. Colloids Surf A Physicochem Eng Asp 2018; 537 : 92-101.

Zheng G-B, Kouda K, Sano H, Uchiyama Y, Shi Y-F, Quan H-J. A model for the structure and growth of carbon nanofibers synthesized by the CVD method using nickel as a catalyst. Carbon N Y 2004; 42: 635-640.

Zheng M, Ji G, Wang Y, Cao J, Feng S, Liao L, Du Q, Zhang L, Ling Z, Liu J, Yu T, Cao J, Tao J. A new restriction effect of hard templates for the shrinkage of mesoporous polymer during carbonization. Chem Commun 2009; 5033-5035.

Zhou G, Xiong T, Jiang S, Jian S, Zhou Z, Hou H. Flexible titanium carbide-carbon nanofibers with high modulus and high conductivity by electrospinning. Mater Lett 2016a; 165: 91-94.

Zhou Y, He J, Wang H, Qi K, Ding B, Cui S. Carbon nanofiber yarns fabricated from co-electrospun nanofibers. Mater Des 2016b; 95: 591-598.

Zhu H, Li X, Ci L, Xu C, Wu D, Mao Z. Hydrogen storage in heat-treated carbon nanofibers prepared by the vertical floating catalyst method. Mater Chem Phys 2003; 78: 670-675.

Zhu Y, Zhang JC, Zhai J, Zheng YM, Feng L, Jiang L. Multifunctional carbon nanofibers with conductive, magnetic and superhydrophobic properties. ChemPhysChem 2006; 7 : 336-341. 